\title{
Technological improvement rate estimates for all technologies: Use of patent data and an extended domain description
}

\author{
By \\ Anuraag Singh \\ B.Tech, Mechanical Engineering \\ Indian Institute of Technology Delhi, 2012 \\ Submitted to the System Design \& Management Program in Partial Fulfillment of the \\ Requirements for the Degree of \\ Master of Science in Engineering and Management \\ at the \\ Massachusetts Institute of Technology
}

September 2020

(C)2020 Anuraag Singh. All rights reserved

The author hereby grants to MIT permission to reproduce and to distribute publicly paper and electronic copies of this thesis document in whole or in part in any medium now or known hereafter created.

Signature of Author:

System Design and Management Program

August 7, 2020

Certified by:

Christopher L. Magee

Professor, Institute for Data, Systems, and Society

Thesis Supervisor

Accepted by:

Joan S. Rubin

Executive Director

System Design and Management Program 
THIS PAGE INTENTIONALLY LEFT BLANK 


\title{
Technological improvement rate estimates for all technologies: Use of patent data and an extended domain description \\ by
}

Anuraag Singh

\author{
Submitted to the System Design \& Management Program \\ on August 7, 2020 in Partial Fulfillment of the Requirements for the \\ Degree of Master of Science in Engineering and Management
}

\begin{abstract}
Complex and highly interdependent socio-technical systems are necessary for sustaining, governing, entertaining and nourishing human society. Such systems fulfill their objectives by incorporating everimproving technologies. A systematic understanding of technology and the pace of technical change is thus critical for policymakers and stakeholders to make well-informed decisions and avoid costly mistakes and omissions. This work reviews past work on technological forecasting and decision making and builds on new research to introduce a systematic approach to technological decision-making.

This document describes why information about technology improvement rates matters to technological decision-making, the theoretical framework for doing so, a repeatable methodology and an online system making available this capability to stakeholders. Despite and somewhat because of the complexity of the "whole" socio-technical system, the regularity of constant annual performance improvement is a very strong empirical fact with substantial theoretical underpinning. This regularity lies at the heart of integrating objective data into overall decision processes concerning items affected by the timing of technological change. The methodology uses a broad, easy to use, database of the rates of technological change that covers almost all technologies. We do this by using prior work (accomplished as part of the effort that enabled this thesis) establishing a correspondence of $97.14 \%$ of all patents within the entire US patent system to a set of 1757 technology domains and estimating their rates of improvements.

We describe the development of a new web-based technology search tool and apply the methodology to a case study of the automotive industry. We believe these results herald a new era of data-driven technological decision-making. Using this new framework and the tool, stakeholders can make timely and "good enough" technology forecasts available without requiring extensive modelling initiatives.
\end{abstract}

Thesis Supervisor: Christopher L. Magee Title: Professor, Institute for Data, Systems, and Society 
THIS PAGE INTENTIONALLY LEFT BLANK 


\section{ACKNOWLEDGEMENTS}

To the gods I am indebted for having good grandparents, good parents, a good partner, good teachers, good associates, good friends and kinsmen, nearly everything good. - Marcus Aurelius

Everything I am, everything I know, everything I have, I owe it to my teachers, friends and family. This thesis is dedicated to all of you.

First and foremost, I wish to thank Prof. Christopher L. Magee. Thank you for responding to an "out of the blue" query two years ago and giving me the opportunity to work with you. Thank you for your incredible generosity with your time and for teaching me everything I know about technology, it's structure and its evolution. I will always cherish all our conversations and hope we will continue to work together for years to come. I am truly proud of the work we have done together along with Prof. Giorgio Triulzi which this thesis heavily references and draws from. Thank you Giorgio for introducing me to the world of Pandas and network graphs, for teaching me the finer points of ordinary least squares and for an unforgettable trip to Colombia. To all my colleagues and collaborators at the IDC- Guillermo, Serhad, Sida, Shuo, Jesse, Julie, Alex, it was a pleasure to work alongside all of you and to share our stories. Thank you for the reading sessions and for the delectable dinners and gatherings.

I am extremely grateful also to Prof. Elisabeth B. Reynolds for taking a chance on me and making me a part of the IPC and the Work of the Future Task Force. Thank you for your mentorship, unflinching trust and support. Thank you for the opportunity to explore mobility through its relationship to technology and work- questions with deep personal relevance to me. I can never thank enough, the members of the mobility group- Prof. Jason Jackson, Prof. Susan Helper, Prof. John Leonard, Prof. David Mindell, Kevin Shen, Adelynn Paik, Russell Glynn and Allison Forbes. Working with all of you has been a true pleasure and extremely rewarding. Thank you to all my colleagues at IPC - Laura, Anita and the WTF backbone group at large. The IPC happy hours will be one of the happiest and most enduring memories from MIT. I am also thankful to the wider MIT Work of the Future Task Force, a truly cross-disciplinary group representing the best of MIT. I was humbled to meet true intellectual giants and the most amazing and warm human beings.

I wish to also thank Prof. Russ Tedrake and Prof. David Keith for giving me a much deeper understanding of the world of robotics \& computer science and modelling respectively. I am extremely grateful to the SDM faculty, in particular, Prof. Bryan Moser and Prof. Bruce Cameron as well as Joan and Bill. Thanks to the SDM Class of 2018 - especially my spring project team, the IDJ folks and my classmates whose amazing life experiences were no less instructional and inspiring as the class material. A special thanks to the SDM daredevils for all the soccer memories.

I will forever be indebted to my friends, teammates, colleagues and mentors (in particular, Sumio Yokoyama) at Honda R\&D and THINK Lab for teaching me engineering, professionalism and how to be a truly considerate and caring person. They all are the reason why you meet the nicest people on a Honda.

To Prof. Ambuj D Sagar, who made academics fun but more importantly, something which mattered. Most of what I have learnt about learning to learn, I have learnt from you. Thank you for making the world comprehensible and hence, changeable. Thank you for having faith in me at a time when I didn't. I owe so much to you and hope to make you proud someday.

To Prof. S.R. Kale thank you for making mechanical engineering bearable and for teaching me design. To all my friends at undergrad, from Kapurthala and in Japan, a life without you all would be devoid of all 
fun and color. In particular, thanks to Abhishek, Akshat, Chetan, Chirag, Geet, Rahul and Ritesh for spirited discussions around technology and adding nuance to my thinking as well as this thesis.

To my uncle and teacher, Dr. Mohan Singh, it's a rare privilege to have someone like you in one's life. Watching you, as I grew up, has taught me to strive to live a life of virtue, never stop asking questions and keep looking for the answers no matter how difficult the journey. To Dr. Amritpal Singh, thank you for being an ideal elder brother and for living a life of example. You have always been there when I needed you and you have changed my life in ways I will never be able to express.

To my parents, I can't thank you enough for giving me good values, a happy childhood, for letting me play to my heart's content, for always putting me above everything else and for trusting me and supporting me no matter what crazy thing I decided to do.

To my love, Ritula, this work is as much yours as it is mine. Nothing I did or do, would be possible or be of meaning without you. To you I owe my purpose, sanity and happiness. You are my greatest blessing. As long as you are by my side, I will never need anything else. On to the next one! 


\section{CONTENTS}

ABSTRACT

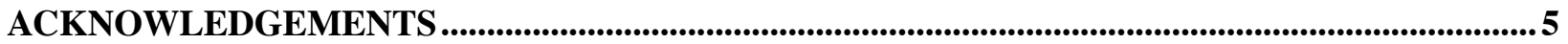

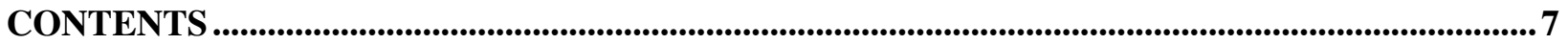

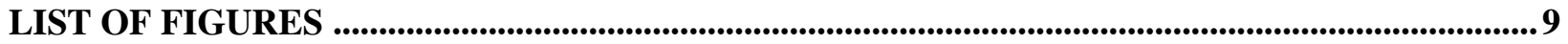

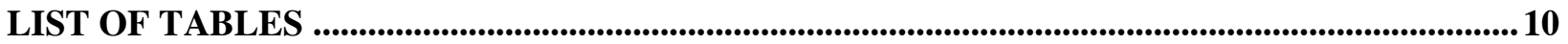

CHAPTER 1 WHY DO TECHNOLOGY IMPROVEMENT RATES MATTER? ...........................11

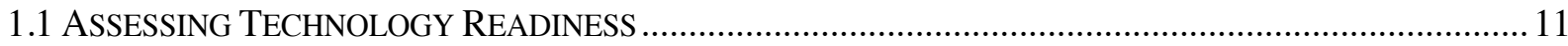

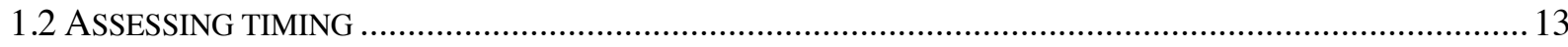

1.3. KEY BUSINESS DECISION SCENARIOS THAT CAN BE SUPPORTED WITH OBJECTIVE DATA ................ 15

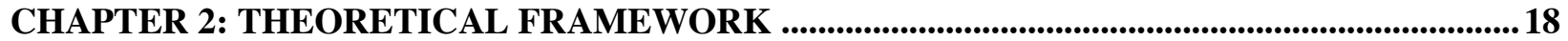

2.1 A TECHNOLOGY DOMAIN DESCRIPTION OF TECHNOLOGY …..................................................... 18

2.2 LONG TERM PERFORMANCE IMPROVEMENTS IN TECHNOLOGIES CAN BE MODELED AS EXPONENTIAL

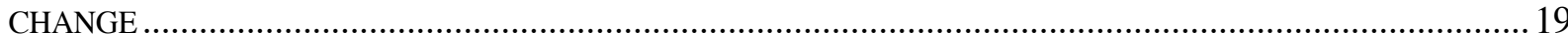

2.3 CLASSIFICATION OVERLAP METHOD (COM) FOR REPEATABLE PATENT RETRIEVAL FOR

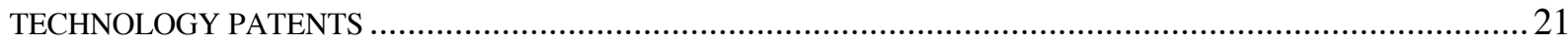

2.4 ESTABLISHING A CORRESPONDENCE OF TECHNOLOGY DOMAINS TO THE US PATENT SYSTEM ........24

2.5 ESTIMATES OF THE RATE OF PERFORMANCE IMPROVEMENT CAN BE MADE BY USING PATENT NETWORK INFORMATION CENTRALITY OF PATENTS BELONGING TO A DOMAIN ................................... 22

CHAPTER 3: DESIGN OF A TECHNOLOGY SEARCH SYSTEM ...............................................26

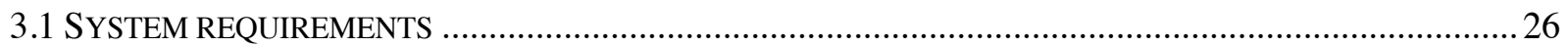

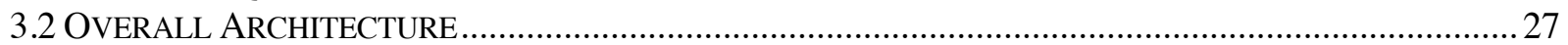

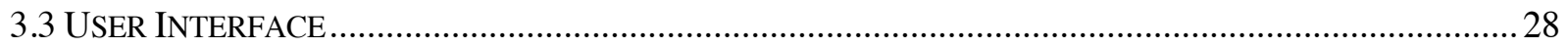

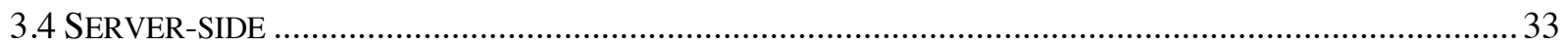

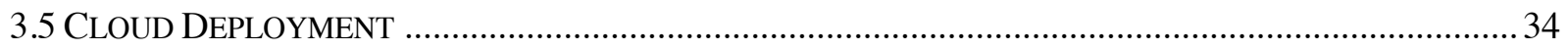

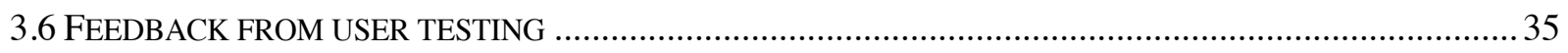

CHAPTER 4: CASE STUDY- AUTOMOTIVE INDUSTRY ......................................................36

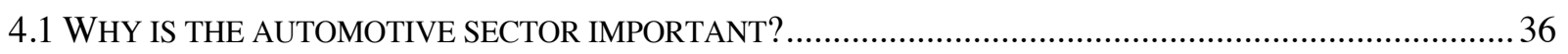

4.2 AN OVERVIEW OF AUTOMOTIVE TECHNOLOGIES AND THEIR IMPROVEMENT RATES ....................... 37

4.3 A MORE DETAILED VIEW OF AUTOMOTIVE TECHNOLOGIES AND THEIR IMPROVEMENT RATES ........ 39

4.4 A SURVEY OF TECHNOLOGIES RELATED TO ELECTRIFICATION ...................................................... 44

4.5 A SURVEY OF TECHNOLOGIES RELATED TO AUTOMATED/ AUTONOMOUS VEHICLES ......................46

4.6 A SURVEY OF TECHNOLOGIES RELATED TO MOBILITY SERVICES................................................. 49

4.7 ELECTRIFICATION TECHNOLOGIES IMPROVE SLOWLY, AUTOMATED/ AUTONOMOUS TECHNOLOGIES

ARE FASTER BUT CONNECTIVITY-RELATED TECHNOLOGIES ARE IMPROVING FASTEST ........................51

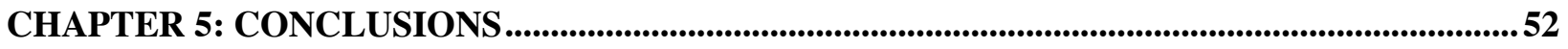

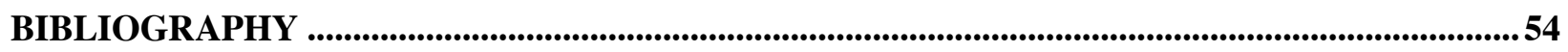


THIS PAGE INTENTIONALLY LEFT BLANK 


\section{LIST OF FIGURES}

Figure 1 TeCHNology IMPRovement AND DifFusion SourCe- Benson AND MAgee (2018)......

FigURE 2 DistRIBUTION OF ESTIMATED IMPROVEMENT RATES (K-VALUES) FOR 1757 TECHNOLOGY DOMAINS AND BEST FIT OF THE PROBABILITY DENSITY FUNCTION. SOURCE- SINGH ET AL. (2020)

FigURE 3 A holistic VIEW of DJANGo's ARCHITECTURE. SOURCE- htTPS://DJANGOBOOK.COM/MDJ2-DJANGO-STRUCTURE/ ............. 27

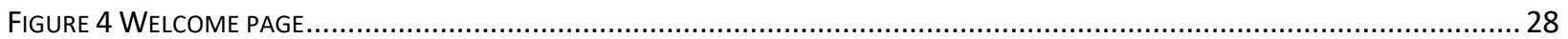

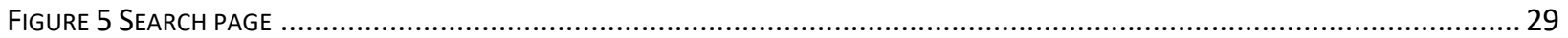

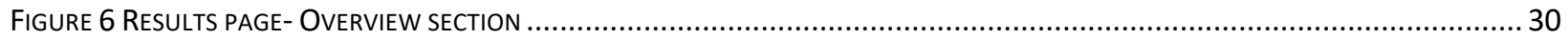

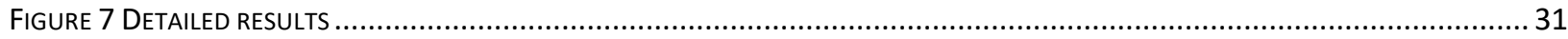

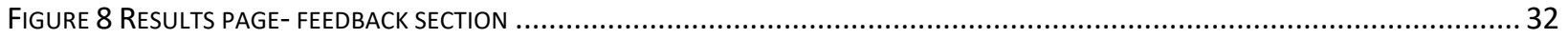

FIGURE 9 DISTRIBUTION OF ESTIMATED IMPROVEMENT RATES (K-VALUES) FOR AUTOMOTIVE TECHNOLOGY DOMAINS CORRESPONDING TO

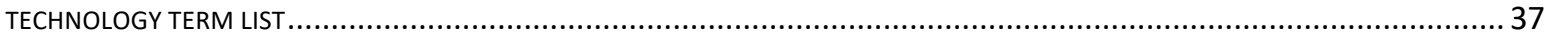

FigURE 10 DISTRIBUTION OF ESTIMATED IMPROVEMENT RATES (K-VALUES) FOR ALL UNIQUE AUTOMOTIVE TECHNOLOGY DOMAINS WITH

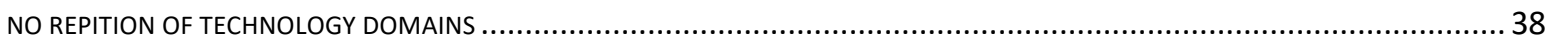

FIGURE 11 DISTRIBUTION OF ESTIMATED IMPROVEMENT RATES (K-VALUES) FOR AUTOMOTIVE TECHNOLOGY DOMAINS CORRESPONDING TO TECHNOLOGY TERM LIST FILTERED BY NUMBER OF MATCHES (GREATER THAN OR EQUAL TO 10) AND MPR (GREATER THAN OR

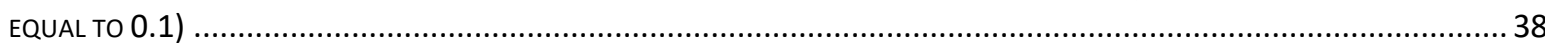




\section{LIST OF TABLES}

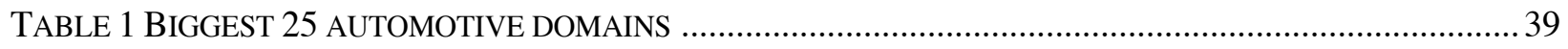

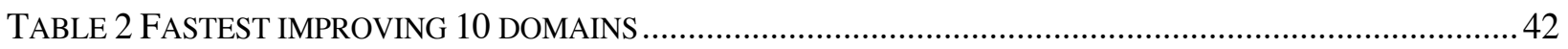

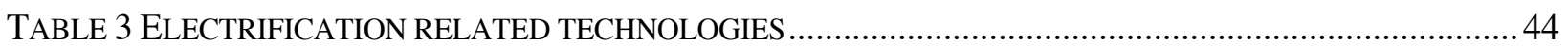

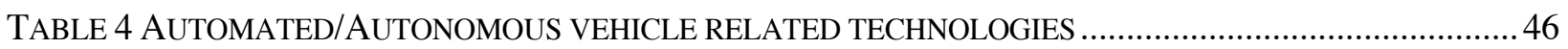

TABLE 5 CONNECTIVITY ENABLED MOBILITY SERVICES RELATED TECHNOLOGIES ................................. 49 


\section{CHAPTER 1: WHY DO TECHNOLOGY IMPROVEMENT RATES MATTER?}

Technology decision makers often face the choice of investing in one core technology (believing it to be crucial to their mission/ existence), an alternate technology (a key "disruptor") or multiple technologies to hedge against failure. Information on improvement rates is crucial in making best choices in such allocation decisions. Although such decisions are made at a point-in-time, it needs to be recognized that they deal with outcomes that are changing (sometime rapidly) with time.

\subsection{Assessing Technology Readiness}

Often times for a key alternate technology (“disruptor”), subjective expert opinions assess when the specific technology will be ready. There are fundamental challenges with this approach in addition to the normal issues with subjectivity. New technologies are often over-hyped (to the extent that there is now a well-known model called the Gartner hype cycle). The creators of the technology and those covering them often have an incentive in overstating when they will be ready (J. Funk, 2019). Decision-makers can be led astray by lab vs real product behavior and leadership can begin to dangerously believe in "reality distortion" due to their or their team's overly high self-assessment. This can lead to large losses for multiple stakeholders including investors, consumers/users, employees and often times general public. Some examples include-probable over-valuation of Uber and others due to very wrong estimates of viability timing for autonomous cars, medical harm due to Theranos, busts in virtual reality and other cases which are essentially about incorrect, overly eager, estimation of timing for potentially valuable technologies.

All technologies require relatively long periods of technology development before they become market ready and an under-estimation of the time to completion can lead to loss of trust, serious disillusionment and withdrawal of a support causing collapse of critical mass of knowhow (for instance, the Artificial intelligence "winters", the collapse of cleantech in US among others). Furthermore, investing in a new technology too early can lead to substantial costs (due to long investment periods without revenues) and ultimately unrealized benefits as the competitors may catch-up quickly and be more effective at marketing as well as establishing a "dominant" design (the innovators of the smart phone- IBM Simon and other innovators only received losses for their innovative behavior while the well designed and well-timed (more than a decade later) iPhone made a fabulous fortune for Apple). On the other hand, there is also a serious risk of under-estimating an upcoming technology. This can be especially critical if the upcoming 
technology threatens the core-technology underlying the main product of the incumbent- examples include Blockbuster, Nokia, Research in Motion (Black Berry) Barnes \& Noble and others.

Thus, it is important for technology managers of all kinds to make accurate estimates of technology timeliness/readiness. It follows that most technology managers consider the rate of improvement of performance for a technology as an important indicator of the potential future importance of that technology (Hoisl et al., 2015). Limitations on acting on that correct intuition include the lack of objective information about rates of improvement and the lack of clarity about the methodology to use that information most effectively. 


\subsection{Assessing timing}

Many detailed studies of specific instances of technological change show that three distinct but interactive elements always play a role. These are scientific knowledge discovery, creative invention and product/service/system development which is essentially about integrating the invention(s) into the socioeconomic system. These studies also show widespread "spillover" of knowledge from one invention to another (in different technological domains), from one field of science to another and from many different fields of science to many diverse technological domains. This reality leads many to believe -somewhat correctly- that prediction of all the specific aspects of a key technological change is not feasible. However, if we examine the question at a higher level, we find that this widespread "spillover" is an important determinant of the major regularity that our method exploits. This regularity is that each technology has a fundamental and constant $\%$ change in improvement per year. The core of our methodology is to determine the timing at which one product, system or service is overtaken by a novel one because these constant rates of improvement are greater for key technology in the novel product vs. the target or existing product based upon its key technologies.

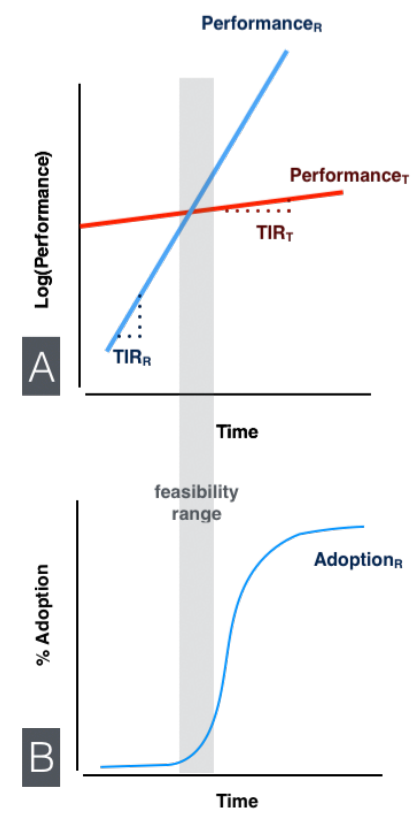

Figure 1 Technology improvement and diffusion Source-Benson and Magee (2018)

Figure 1 describes this core concept in graphical form. The more rapid improvement in the disrupter technology eventually leads to superior performance for that technology and it is at or near the cross-over that the adoption of the disrupting product rapidly accelerates ("takes off"). Identifying a technology "just" when it's about to take-off in the S-curve model of diffusion and investing significantly in product 
development, marketing/ sales at that time, can allow a firm to gain market share quickly and establish a “dominant design" (Benson \& Magee, 2018). In addition, there is evidence that faster improving technologies are also adopted at a faster rate during their infancy (Woo \& Magee, 2018). This can allow for more accurate estimates of expected sales during the infancy of a technology and can provide a guide for creating realistic technology development and sales roadmaps. 


\subsection{Key business decision scenarios that can be supported with objective data}

This section describes key business decision scenarios where a firm could benefit from the use of objective technology imptovement rates data.

\subsubsection{Analyzing promising new technologies based on their rate of improvement}

Often times, firms make assessments concerning a key technology that they depend on, to determine whether it is "ready"/ cost competitive to incorporate in their products/systems. This is especially true for new use cases or fundamentally new product development. It is important to recognize that these questions are always a difficult assessment of when (including ever) a given technology is going to be good enough to provide value compared to the current incumbent. The adoption analysis described in Figure 1A requires estimates for the time dependence (slopes) of the curves. Often times this is done by large consultancies and academic consortia over multiple years. Many times, businesses will forego these analyses due to the effort involved. A quick and reasonable process to make technology forecasts will help technology managers build data-driven decision making into their normal process flow. Thus, a firm can invest in a technology with a more accurate estimate of when it will be ready, budget for required resources accordingly and better account for shocks likely to be encountered on the way.

\subsubsection{Firm Readiness Analysis}

It's imperative for the firm's leadership to identify important relevant technologies for the future based on its mission and product/system vision and to assess its strength and weaknesses in those technological domains. A firm should assess it's performance in it's core technological domains through objective measures such as total number of patents or more appropriately, total number of important patents.

\subsubsection{Competitor Analysis}

The competitor analysis can help compare a firm's performance in technological domains of interest with its near-term competitors as well as "disruptors" solving the same business problem using the firm's patenting patterns. If a firm is farther behind its competitor in a faster improving technology it might consider collaborating with a partner or acquiring a key capability buy merger/ acquisitions and/or hiring key personnel.

\subsubsection{Acquisition Analysis}

Based on the firm's analysis of its own readiness and of its competitors, it might outsource or invest in startups with those technologies. Corporate venture capital, is increasingly employed by firms when their 
own capabilities are lacking and time for catch-up is limited (because of fast improving rates), or in-house development is inadvisable because of substantial differences in the rate of improvement of its core technology and the required technology. In such a scenario, it may wish to acquire other firms.

However, the process of finding acquisition targets is very ad-hoc and unsystematic. There is considerable friction and often unsatisfactory results for both startups and the large firms. A systematic process to find acquisition targets in the technological domain of interest and evaluating them based on their technological performance can help improve outcomes for both.

\subsubsection{Rapid value analysis for identifying competing technology and firm readiness}

Many times, a firm must evaluate whether a new technology might allow similar or even different product designs to eventually be competitive and surpass their well-established entry. A relatively simple analysis can be done by scenario building using subjective judgement of technology readiness before doing a systematic relative value assessment for the most business-critical cases. For instance, a firm maybe concerned about the potential of technology B disrupting its core competence (technology A). In such cases, the firm quickly builds multiple scenarios regarding the technology B's current state of readiness relative to tech A and estimates an expected time of performance crossover in all the different scenarios. These scenarios can be easily updated over time as more information about technology B's readiness is discovered.

Thus, a firm can more clearly identify competing technologies and whether they are improving faster than the current core technology. They could choose to make investments only in those technologies which seriously threaten its business based on the future scenarios. This will prevent loss of focus caused by false alarms, a persistent problem for many big firms.

\subsubsection{Performing a relative value assessment of competitive products utilizing alternative technologies}

More care is required in business-critical decisions. Since the present offset in Figure 1 involves the relative appeal/ value of competing products that utilize different technologies, a more systematic relative value assessment of such competing products reduces uncertainty about the cross-over point. We have developed methodology which has capability to do this generally and Woo and Magee (2020) demonstrated the methodology with a case study on battery electric vehicles. 
An analysis of user value is accomplished by considering the effect of design changes and other engineering trade-offs, based on relative utility estimates of distinguishing attributes. For the engineering analysis we need a systems technology model. The improvement rates for the competing technologies which would be plugged into the model to create a simulation of possible technological scenarios into the future. However, doing this for new cases requires market and product knowledge that is resident in participants in that market.

In most cases, the firm has a good understanding of the current state of technology and of the performance required for user acceptance of known products. The acceptable performance characteristics are an often underappreciated and very critical part of the estimation process. They can vary significantly with the final form (design) of the product- for instance, there might be a lower threshold of performance for automated low-speed shuttles than self-driving cars. Or as in the case of cameras, a lower threshold for image quality for digital cameras because of ability to store larger number of photos. As such, technology managers need to think broadly when they think about the form and design of the product incorporating the technology.

\subsubsection{Predicting cross-over points and creating realistic technology development and sales roadmaps}

A related use case is that of determining take-off point in the product adoption S-curve of a newly competitive product based on a different (faster improving) technology. A more accurate estimate of the cross-over point can facilitate market entry just in time to capture substantial market share and establish a dominant design. In addition, a firm would be able to make better capital allocation decisions by only investing in serious competing technologies with better timing rather than subsidizing loss-making research at an external entity.

Prior research has demonstrated that there is a high correlation between a technology's improvement rates and its adoption, especially during its infancy- from $0-10 \%$ adoption and from 10-30\% adoption (Woo \& Magee, 2018). This is also the period of greatest uncertainly. As such even a slightly better estimate of timeline of adoption and estimates of sales can lead to massive amount of savings preventing both over and under-capacity 


\section{CHAPTER 2: THEORETICAL FRAMEWORK}

In this section, we describe the major conceptual ideas underpinning this work- first, a technology domain description of technology; second, models of long-term technological performance improvement; third, retrieval of patents belonging to a particular technological domain using COM; fourth, estimating rate of improvement using patent network information centrality; and fifth, establishing a correspondence of technology domains to the US patent system and calaculating improvement rates for all the domains. This chapter borrows heavily and reproduces some sections verbatim from Singh et al. (2020) with permission from co-authors.

\subsection{A technology domain description of technology}

(this passage has been borrowed from Singh et al. (2020) and reproduced with the permission of coauthors)

A crucial advance in the field of technology studies came from the development of precise definition of technology and the diffusion of a shared understanding of it. In his seminal work, Dosi (1982) defines technology as combinations of "theoretical" and "practical" know-how, methods, processes, experiences as well as their embodiments in physical devices and equipment. Arthur adds a complementary perspective and defines technology as "a means to fulfill a purpose, and it does this by exploiting some effect" in his work, the structure of invention (Arthur, 2007). Magee et al. (2016) have built on prior work by Dosi and Arthur to define Technological Domain (TD) as "The set of artifacts that fulfill a specific generic function utilizing a particular, recognizable body of knowledge.” This definition introduces TD as a means to avoid the confusion associated with the word technology which has come to mean widely different things to different people. Magee et al. (2016) have further employed the concept of technological domains to obtain reliable empirical estimates of technology improvement rates for 30 domains over periods of decades.

In sum, the field of research of technological change now has precise definitions of what technology is, how it evolves, why it does it in ways that differs across sectors and countries and how they affect economic growth differentials at these two levels. Nevertheless, despite these extensive efforts to study what determines the direction of technological change and how it evolved in selected industries, the rate of improvement of technological advances and its differences across technologies, a key determinant of economic growth differentials, has not been studied convincingly and systematically. Our work aims at contributing to filling this gap. 


\subsection{Long term performance improvements in technologies can be modeled as exponential change}

(this passage has been borrowed from Singh et al. (2020) and reproduced with the permission of coauthors)

A consistent body of empirical evidence shows that performance improvements for individual technologies follow exponential trends over the long-term, consistent with constant yearly rates of improvement (Moore, 1965; Martino, 1971; W.D. Nordhaus, 1996; Moore, 2006; Koh \& Magee, 2006; W. Nordhaus, 2007; Koh \& Magee, 2008; Koomey et al., 2011; Nagy et al., 2013; Farmer \& Lafond, 2016; Magee et al., 2016). Studies of large sets of such data (Farmer \& Lafond, 2016; Magee et al., 2016) agree that random walk around the exponential (constant yearly \% increase) is the most appropriate description. Short term segments of these noisy exponentials can be described as $\mathrm{S}$ curves but these do not hold up in the long-term as evident in the Farmer and Lafond analysis (2016). Moore's law (1965) is the single most famous example of exponential long-term technology improvement. Thus, we refer to the fact that all domains show this exponential behavior as the Generalized Moore's Law (GML).

The performance of many technologies over time $Q_{l}(t)$ can then be expressed by the following mathematical description given in Equation 1. $Q_{i}$ represents the intensive performance metric, subscript $i$ denoting technological domain $i$ and subscript 0 denoting time equals $t_{0}$.

$$
Q_{i}(t)=Q_{i 0} \exp \left\{k_{i}\left(t-t_{0}\right)\right\}
$$

The exponential factor $\left(k_{i}\right)$ in Equation 1 is domain dependent. While different technologies all improve exponentially, they do so at different rates (Koh \& Magee, 2006, 2008; Magee et al., 2016). However, $k_{i}$ is constant (at least to a good approximation) over time in a domain (Farmer \& Lafond, 2016) and for different productivity metrics within a domain (Magee et al., 2016).

The characterization of innovation as a combinatoric process of existing ideas (Usher, 1954; Ruttan, 2000; Fleming, 2001; Fleming \& Sorenson, 2001; Frenken \& Nuvolari, 2004; Frenken, 2006c, 2006a, 2006b; Weisberg, 2006; Gruber et al., 2012; Youn et al., 2015) has been suggested to explain why exponential improvements are observed (Youn et al., 2015; Basnet \& Magee, 2016). Furthermore, fundamental properties of a technology domain, such as scaling laws and the complexity of interactions between the components artifacts, have been conjectured to determine differences in rate of performance improvement across domains (Dutton \& Thomas, 1984; McNerney et al., 2011; Basnet \& Magee, 2016). 
Thus, while the form of Equation 1 seems to suggest that performance depends only on an exogenous time-trend, it captures improvements due to science, spillover from other technologies, scaling (increase in production) and complexity of interactions (modularity).

A different description for decrease in cost and increase in performance, is based on the observation that cost of many technologies decreases as a power law with cumulative production. The phenomenon is known as an experience curve, learning curve, or Wright's law suggesting learning-by-doing processes as the possible cause (Wright, 1936; Argote \& Epple, 1990). Ayers and Martinàs (1992), taking a more expansive view, argue that the experience curve is not just related to learning-by-doing but an indirect measure of total effort, including “... incremental design improvements, increased capital intensity in the manufacturing process and (closely related) economies of increasing scale”. However, experience curves and their conceptualization as examples of learning-by-doing have been subject to criticisms. Nordhaus (2014) has shown that there is a fundamental statistical problem in separating learning processes from exogenous technological change during modeling and attributing causality. Sinclair et al. (2000) as well as Funk and Magee (2015) have shown the important role of R\&D which is missed in simple models based on experience curves. Magee et. al (2016) examined the relationship of the number of patents over time with technical performance and found that Moore's Law holds even when the number of patents do not increase exponentially with time. This suggests that Moore's Law is fundamental over the long-term and independent of "effort" variables such as total number of patents ${ }^{1}$.

The empirical evidence on Moore's and Wright's law and the apparent difference in interpretation, can be reconciled by the mathematical fact that the two laws are equivalent as long as cumulative production increases exponentially over time (Sahal, 1979; Nagy et al., 2013; Magee et al., 2016). More recently, Lafond et al. (2020) have shown that growth of experience (measured by cumulative production) and an exogenous time trend (excluding cumulative production) contributed roughly equally to the decreases in cost of military products during world war 2 .

\footnotetext{
${ }^{1}$ Past studies have shown that number of patents are significantly correlated with the research "effort" in the domain measured by investment- specifically R\&D spending. See Griliches, Z., 1990. Patent Statistics as Economic Indicators: A Survey (Working Paper No. 3301). National Bureau of Economic Research. https://doi.org/10.3386/w3301 for an excellent review.
} 


\subsection{Classification Overlap Method (COM) for repeatable patent retrieval for technology patents \\ (this passage has been borrowed from Singh et al.(2020) and reproduced with the permission of co- authors)}

The patents corresponding to technological domains defined above can be reliably found using the classification overlap method (COM) described by Benson and Magee (2013, 2015a). COM is an improvement over the traditional keyword search and the classification search and makes patent retrieval repeatable. The usage of two separate hierarchical classification systems by the USPTO (up to mid 2015) allowed distinction between function and knowledge base (the two basic concepts underlying technological domains) to be built into the classification scheme. The resulting success of COM in retrieving patents that are consistent with the artifacts whose performance improvement is measured in the domains is the fundamental reason for expanding the coverage to previously unidentified domains in

the current work. Operationally, the normal use of COM first retrieves all patents using a pre-search based set of keywords (in the patent title or abstract), companies or individual inventors. The most representative technology classes belonging to both International Patent Classification (IPC) and the United States Patent Classification (UPC), are ranked using an objective score. It is important to note that many patents are classified into multiple classes (Benson and Magee, 2015a; Magee et al., 2016) and so a patent might appear multiple times in each of the most representative technologies. Finally, all patents that have been classified in both the topmost representative IPC class and the topmost UPC class are retrieved for that domain. 


\subsection{Estimates of the rate of performance improvement can be made by using patent network information centrality of patents belonging to a domain}

(this passage has been borrowed from Singh et al.(2020) and reproduced with the permission of coauthors)

By far, the most accurate and reliable indicator is a measure of the centrality of a technology's patents in the overall US patent citation network, as shown in Triulzi et al. (2020). More precisely, technologies whose patents cite very central patents tend to also have faster improvement rates, possibly as a result of enjoying more spillovers from advances in other technologies and/or because of a wider use of fast improving technologies by other technologies, proxied by patent citations. The measure of patent centrality used is a normalized version of the "Search Path Node Pair" (SPNP) index proposed by Hummon and Doreian (1989) and operationalized in a fast algorithm by Batagelj (2003) for directly acyclical graphs and popularized by, among others, Verspagen (2007) to identify the main paths of technological development in a patent citation network. The SPNP index is a measure of information centrality, conceptually similar to the random-walk betweenness centrality. It measures how often a given node shows up on any path of any length connecting any given pairs of nodes in the network. Therefore, central patents are like information hubs in the citation network, representing inventions that are related technologically by a path of improvements to many other inventions that appeared before and after them.

Triulzi et al. (2020), normalized the centrality index by randomizing the citation network under a set of constraints, such as the indegree and outdegree of each patent, the share of citations made by each patent that goes to the same main technology field of the focal patent and the age of the citing-cited pair for each citation (for more information see Appendix B in Singh et al. (2020)). This makes centrality comparable for patents granted in different moments in time and assigned to different technology fields, which, in turn, allows computing a comparable average centrality for patents across technology domains. The latter was shown to have a correlation of 0.8 with the log of the yearly improvement rate. As a result, the authors showed how the following estimated equation, trained by running a regression for the 30 technologies for which observed improvement rates are available, can be used for out-of-sample predictions of the improvement rate of any given technology domain i for which an accurate patent set can be identified ${ }^{2}$.

$$
\text { Estimated } K_{i}=e^{\left(6.16 * X_{i}-5.02\right)} * e^{\frac{\sigma_{i}^{2}}{2}}
$$

\footnotetext{
${ }^{2}$ For a discussion of the prediction intervals of the estimation we refer to Triulzi et al. (2020).
} 
In Equation 2, numbers inside the bracket are the estimated coefficients of an OLS regression that has the $\log$ of the improvement rate as dependent variable, an intercept and one predictor $X_{i}$ for each technology domain $i$. In Triulzi et al. (2020), this predictor is the mean value for all patents in domain $i$, of the average centrality of the patents cited by each patent $j$ in domain $i$. The second term in the right-hand side is a correction factor to move back from a log scale to a linear scale. 


\subsection{Establishing a correspondence of technology domains to the US patent system and calculating improvement rates for all the domains}

(this passage is based on Singh et al. (2020) and the reader is referred to the publication for full details)

Based on the concept of technology domains (section 2.1) and the discovery of patents belonging to a particular domain using the classification overlap method (COM) described in Section 2.3, Singh et al. (2020) extend, invert and automate COM to give a technology domain description for almost the entire patent system. One class from the UPC list and one from the IPC list is chosen and all patents which belong to each of those classes are found using the classification data. This gives the "overlap" between these two sets- the patents which lie in both the given IPC class as well as the given UPC class. This is done for all possible class pairs i.e. unique combinations of classes- one from IPC and one from UPC and thus define the full set of overlaps. All overlaps are potentially domains but only if a large enough set of patents occupies the overlap. Since some patents lie in multiple UPC and multiple IPC classes (as discussed in Section 2.2), some patents naturally lie in more than one overlap. For simplicity and ease, they are assigned to the largest overlap so that the final decomposition lists each patent in only one domain. For the purposes of technology improvement rate this does not make a big enough difference (see Appendix A in Singh et al. (2020)) to concern us as this work is focused on rates of improvement. In research on technological structure, the duplicated lists would be used as well but this is beyond the scope of the current work. Deduplication empties a number of small overlaps and reduces the number of patents in others. Going forward, by size we mean the number of unique patents after deduplication.

Using the steps outlined abovc, Singh et al. (2020) obtained 1757 domains describing $97.2 \%$ of the US patents from 1976 to 2015. Following the methodology from Triulzi et al. (2020), outlined in section 2.4, Singh et al. (2020) further obtained the estimated improvement rates for all 1757 domains.

However the centrality measure used to estimate improvement rate was modified. Instead of using average normalized centrality of the patents cited by a domain's patents, Singh et al. (2020) used the normalized centrality of the focal patents in a domain computed after three years from the moment the patent is granted. The following equation, adapted from Triulzi et al. (2020), was used for estimation of the improvement rate.

$$
\text { Estimated } K_{i}=e^{\left(6.22 * X_{i}-4.97\right)} * e^{\frac{\sigma_{i}^{2}}{2}}
$$


The coefficients were obtained by training an OLS regression of the log of the observed improvement rate for 30 technologies (for which empirical time series of performance over time were available) against the average normalized centrality of their patents measured three years after being granted $\left(X_{i}\right.$ in the equation). The improvement rates for these 30 technologies and their patent sets with centrality values are the same used in Triulzi et al. (2020).

For each of the 5083263 utility patents granted by the USPTO between 1976 and 2015, the normalized centrality index was computed using the same citation network randomization procedure presented in Triulzi et al. (2020). The average centrality of patents in each of the 1757 identified technology domains was computed and plugged into equation (3) to obtain the estimated yearly performance improvement rate. Hence, the distribution given in Figure 2 was obtained. Figure 2 shows the distribution of the estimated improvement rate values for the 1757 domains and the best fit for the probability density function. The distribution is very skewed and its best fit is log-normal. More than $82.7 \%$ of the technological domains are improving at a rate of less than $25 \%$ per annum and more than $60 \%$ at a rate less than $12.5 \%$. Performance for the average technology improves at a rate of $19.19 \%$ a year, with a standard deviation of 0.2625 (i.e. $26.25 \%$ per year).

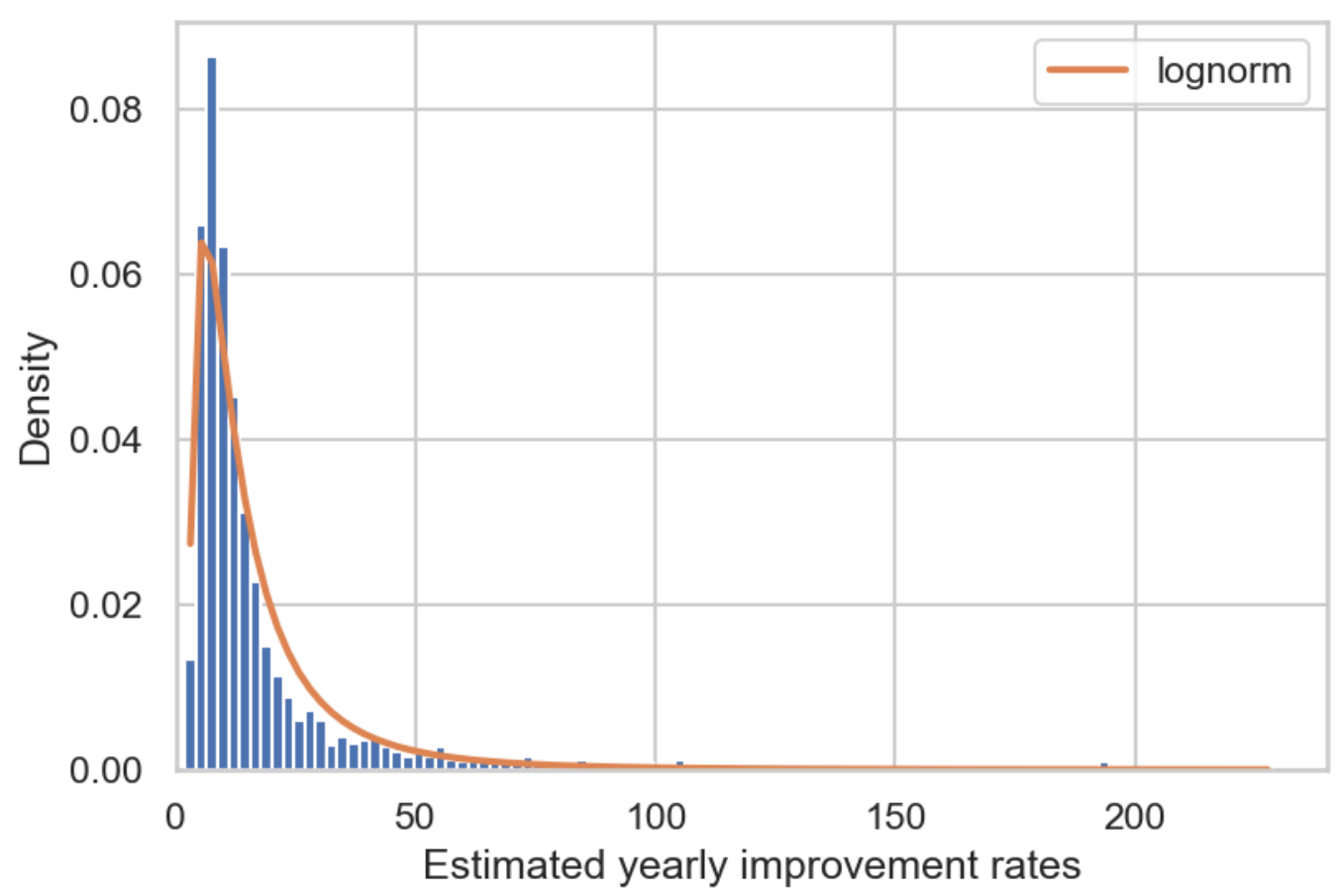

Figure 2 Distribution of Estimated Improvement rates (K-values) for 1757 technology domains and best fit of the probability density function. Source-Singh et al. (2020) 


\section{CHAPTER 3: DESIGN OF A TECHNOLOGY SEARCH SYSTEM}

Since the motivation for the project is to help policy-makers make better decisions, it is important to make the research available in a user-friendly manner. Due to the wide variety of technologies likely to be of interest to the various stakeholders as well as the success of the search paradigm for information retrieval, a technology search system was developed- as the most suitable framework- for presenting information to users to integrate into their decision-making workflow.

\subsection{System requirements}

The key requirements for the system were determined to be as follows-

1. The system shall accept a query from a user (including multiple strings)

(Also, needs to show an introduction and some instructions on the same page)

2. The system shall search a very big database (4GB) for matching entries under 1 second

3. The system shall perform calculations using results from the search and a smaller database (less than $1 \mathrm{mb})$

4. The system shall output a table with about 5 entries based on results from step 3

5. Each entry in the above table shall be clickable and shall lead to detailed results with another table containing about 20 entries from a different database (less than $10 \mathrm{mb}$ )

6. The tables shall be scrollable. 


\subsection{Overall Architecture}

To meet the requirements outlined above we created a custom dynamic web-application capable of search and calculations. A static website is generally much easier to do but limited in functionality and the range of capabilities it makes available to the user. Python has become one of the most commonly used software programming languages. As such, to ensure future maintainability, adequate support and availability of technical expertise, a python-based web-framework was deemed the most suitable for the web search system.

There are two major python-based web-frameworks- Flask and Django. Due to the requirement of dealing with a large database and Django's suitability for dealing with search and cloud deployment, Django was selected. Figure 3 describes the Django framework. There is a clear separation in Django between the client-side and the server-side. The client-side primarily consists of the user interface. These are implemented using Django templates which are written in HTML and/or CSS and are not much different from conventional website design. The server-side consists of data management as well as the operations on the data while meeting user-queries. The key functional elements on the server side are the "model" and the "view", in addition to the database which is independent of the framework. Taken together, this represents a client-server architecture with model-view-template. These are explained in more detail in the following sections.

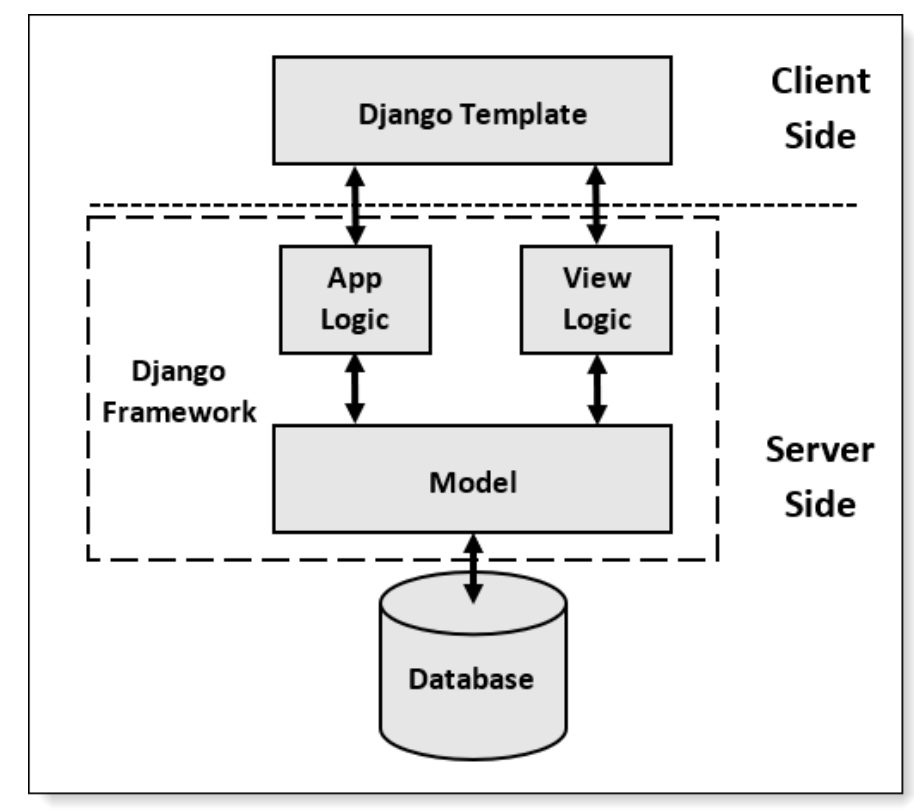

Figure 3 A holistic view of Django's architecture. Source-https://djangobook.com/mdj2-django-structure/ 


\subsection{User Interface}

This primarily consists of the graphical user interface and the client side of the web framework. The following sections describe the user interface elements in some detail.

\subsubsection{Welcome page with instructions}

Since this is a new kind of tool, it was felt that some hand-holding will be necessary for new users. As a user grows familiar with the interface and the capabilities of the tool, the instructions will go away. Figure 4 shows the instruction interface-

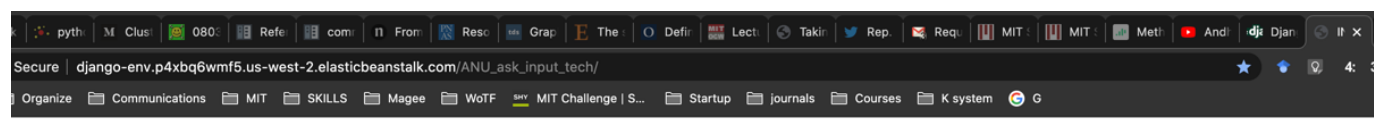

WELCOME TO TECHNOLOGY SEARCH PORTAL BY MIT IDC

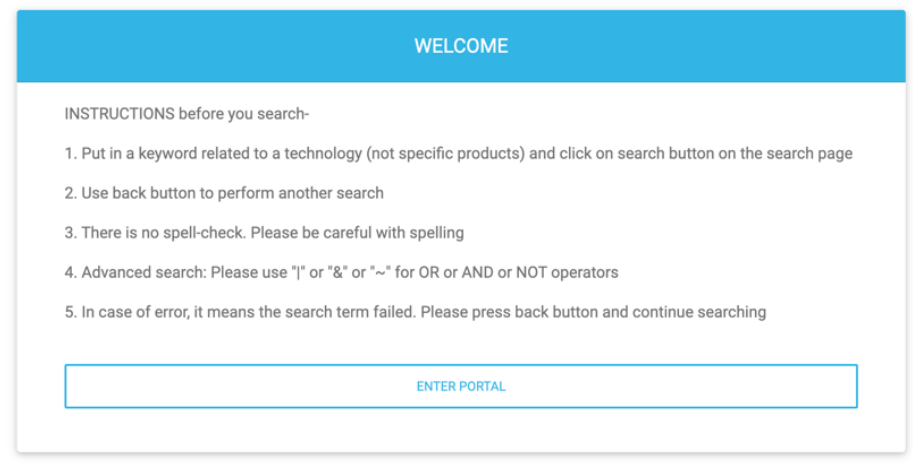

Figure 4 Welcome page 


\subsubsection{Search page}

Entering the portal takes the user to the search page. The search page is minimal, distraction free and focuses on the search box as well as the search button. In order to help a new user, the search box incorporates a technology term prompt as shown in Figure 5.

\section{WHICH TECHNOLOGY DO YOU WANT TO SEARCH FOR?}




\subsubsection{Results page- Overview section}

The results overview section is primarily composed of a table summarizing the improvement rate of the top 5 matching technological domains. The table lists the following key pieces of information for each technology domain-

- Domain ID is a unique identifier for each technology domain and also the portmanteau of the parent UPC class and the parent IPC subclass of the domain. Clicking on the Domain ID takes the reader to the Top 20 patents for each domain, allowing them to qualitatively assess the quality of match

- Estimated Improvement Rate (p.a) is the annual improvement rate of the technological domain in percent. To help the user interpret the results it its noted that a rate above $42 \%$ means the technology is improving faster than integrated chips, made famous by Moore's law (1965)).

- Domain size is the number of patents in the technology and Patents Matched is the number of patents which contain the keyword you searched for.

- $\quad \boldsymbol{M P R}$ as a quantitative measure of relevance as described in section 3.4.2.

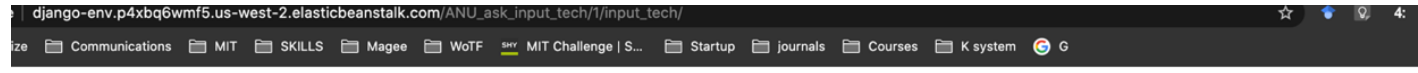

2371 patents found for search term "turbocharger"

Continue Searching or scroll down to provide feedback. Please click Domain ID to read Top20 patents for each domain.

ESTIMATED IMPROVEMENT RATES FOR TOP 5 MATCHING DOMAINS

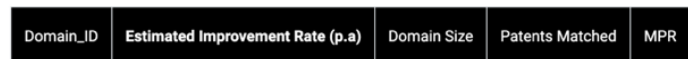

\begin{tabular}{|l|l|l|l|l|}
\hline$\underline{60 F 02 B}$ & 23.0 & 1245.0 & 515 & 0.32 \\
\hline$\underline{60 F 02 D}$ & 79.5 & 171.0 & 51 & 0.16 \\
\hline$\underline{123 F 02 B}$ & 14.0 & 20448.0 & 555 & 0.13 \\
\hline$\underline{415 F 01 D}$ & 7.3 & 7683.0 & 344 & 0.09 \\
\hline$\underline{60 F 01 N}$ & 64.7 & 6832.0 & 137 & 0.04 \\
\hline
\end{tabular}

Estimated Improvement Rate (p.a) is the annual improvement rate of the technology in percent. If it's above $42 \%$ that means the technology is improving faster than integrated chips (Moore's law).

Domain size is the number of patents in the technology and Patents Matched is the number of patents which contain the keyword you searched for.

We use MPR as a measure of relevance and anything above 0.3 is usually a decent match. Top 20 patents from the domain are a good indicator of whether the technology matches

PROVIDE FEEDBACK

Figure 6 Results page- Overview section 


\subsubsection{Detailed Results page}

As described in section 3.3.3, clicking on the Domain ID takes the user to the top 20 patents from each domain. The detailed results were originally envisaged to be displayed within the results page but it was observed that this resulted in the results page becoming overloaded with information and creating too much cognitive overhead. Thus, the results were hidden away and linked to the main table using the Domain ID.

The patents are ranked by their average centrality using the centrality measure described in section 2.2.

For each patent, we provide the patent number, title, abstract and the name of the assignee.

Figure 7 shows the detailed results with top 20 patents from domain 60F02B-

TOP20 PATENTS FROM DOMAIN 60F02B.

Please press browser back button to go back to results.

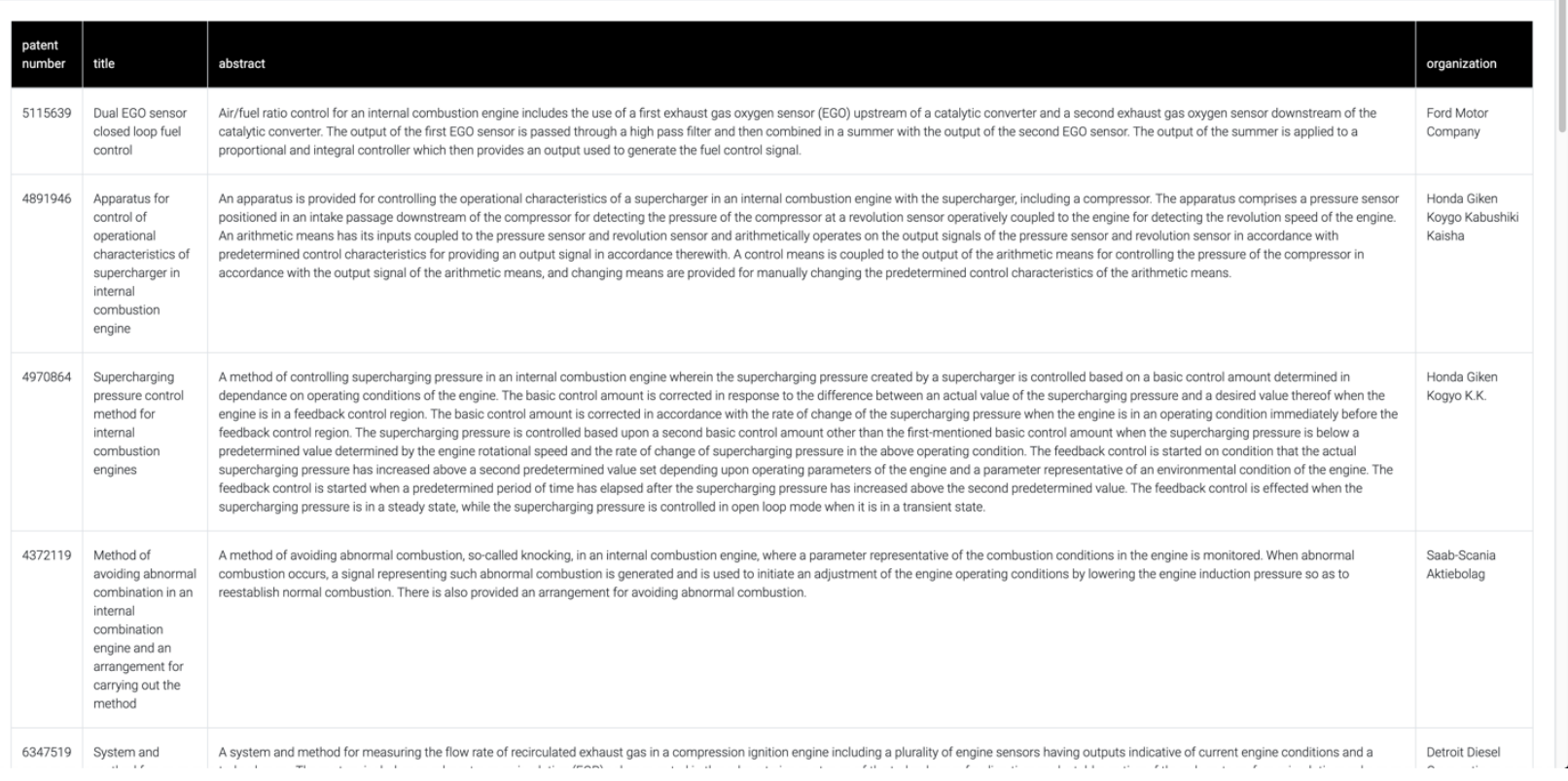

Figure 7 Detailed results 


\subsubsection{Results page- Feedback section}

The feedback section follows the overview section in the results page and is accessed by scrolling down. A key goal of the feedback section was to leverage the advantages of an online system by improving the system with user feedback. By accepting feedback, we can to continue to develop a deeper connection between popular technology terminology and the 1757 domains described in section 2.4. The feedback section is minimal with two questions assessing accuracy and preciseness, two blanks with prompt for user input and legend for calibrating the score.

\section{PROVIDE FEEDBACK}

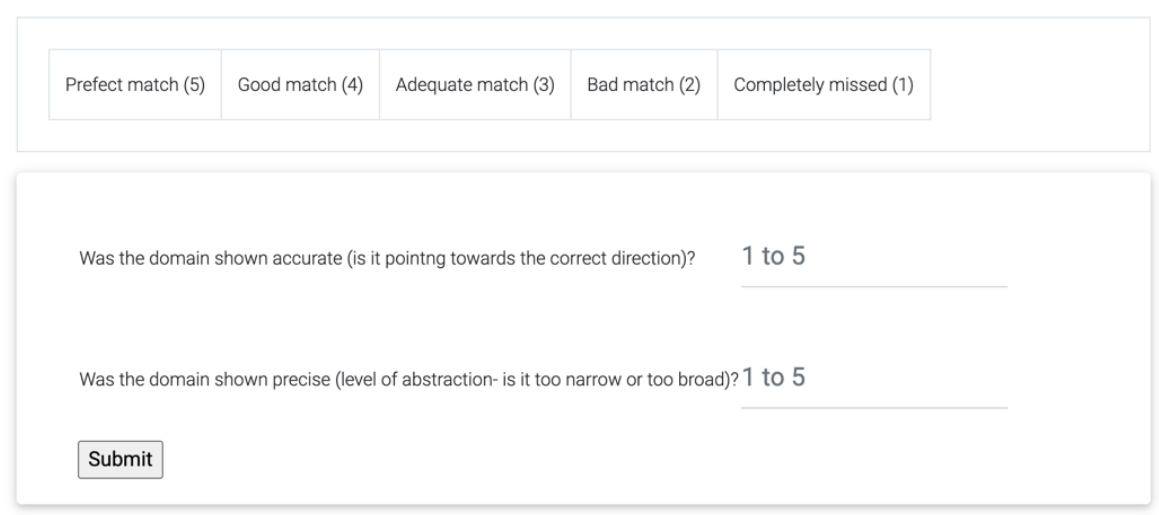

Figure 8 Results page-feedback section 


\subsection{Server-side}

The following section describes some of the key backend functions that were accomplished with the web application. These functions could be implemented with a different web-framework (such as Flask or JavaScript plus NodeJS), using a similar architecture (client-server with model-view-template) or with a completely different architecture (such as a serverless architecture).

\subsubsection{Database and Full text search implementation}

The patent title and abstract are combined into a single text field and stored along with the patent number and the corresponding domain ID. The choice of database is independent of the web framework used and Django is flexible enough to deal with different kinds of databases. However, the size of the database ( 4GB) and requirement of fast search required considerable optimization for full text search implementation.

For each given search term, we search patent title and abstracts across the entire dataset of valid US utility patents (with grant dates between 01-01-1976 to 06-01-2015) and return the list of patent numbers containing the term. To search a database of this size required up to 300 seconds on a PC of normal configuration (dual core processor with enough RAM). A waiting period this long, would be a serious impediment to user experience and would kill the interactive nature of the tool. Considering we would have to host the technology tool on an online server for a considerable length of time a much larger configuration was out of the question due to the costs involved.

We were finally able to solve this by using an inverted index on a relational database- specifically Generalized Inverted Index on PostgreSQL (a relational database like MySQL etc.). The idea behind using an index is the same as an index for a book. Indexing also incorporates tokenization, stemming and vectorization to cut down on the total number of words we will have to look-up. It has to be noted that this necessitates an increase in the size of the database as we have to store the database along with the index. However, since storage tends to be cheaper than processing power, this was a tradeoff well-worth making. Ultimately, we cut down the worst-case search time to less than 2-3 seconds for large queries on the same configuration. For most queries, the search was instantaneous. By using a slightly larger configuration, we were able to make the online system load results faster than a Google search (although Google looks up a much-much larger index and is providing much a greater diversity of results). Our system was typically able to load results under 250 milliseconds and under 300 milliseconds for the 
largest queries we could make, which was consistently faster than most google queries in our testing (measured using Chrome DevTools).

\subsubsection{Calculations on the query}

Using the full text-search described above calculations were made on the results returned by the database. These calculations are made within a Django "view", an abstraction consisting of Python code which interacts with the database through the abstraction of a "model" and returns graphical objects which can be rendered by the "template".

A model is a data-object with certain attributes. For instance, each separate patent is described by a model which contains patent number, combined text of title and abstract as well as the corresponding domain. In our case, the "view" accepts the user query, formats it and sends it to the database. The results from the database are then processed using simple algorithms written in Python code. We group the list of patents retrieved by their corresponding technology domains by using the correspondence established before. We find the most representative domain for those patents by using a relevance ranking. The relevance ranking for the patent classes is accomplished by using the mean-precision-recall (MPR) value proposed by Benson and Magee (2013). This value was inspired by the ' $F 1$ ' score that is common in information retrieval, but uses the arithmetic mean (instead of the geometric mean) of the precision and recall of a returned data set (Magdy and Jones, 2010). Finally, the "view" returns the top 5 most representative domains along with an estimate of the improvement rate for each domain as an HTTP object to the user side and the table is displayed using the "template". The view also returns the title and abstract of the top 20 patents from the most representative domains.

\subsection{Cloud Deployment}

To ensure reliable performance, uninterrupted service and effectiveness of cost, the system was deployed to an on-demand cloud computing platform. We chose Amazon Web Services (AWS) for the ease of deployment and availability of detailed documentation as well as support in popular forums. AWS also works well with Django and automatically sets up a computing instance, a storage instance and security protocols for the web application. However, the database needs to be setup separately and needs to communicate with the computing instance. 


\subsection{Feedback from user testing}

About 10 technology managers used the system. Most praised the clarity, speed and specificity of the system. Those who provided detailed feedback wanted an option to look at technologies of interest with more granularity and through firm-related keyword. Some suggested the use of more graphical devices in the results to help the user comprehend the meaning of the rates. Finally, we found that few users were providing feedback in the results. This might be because the feedback section which required a scrolling down to make it unobtrusive had simply become invisible. 


\section{CHAPTER 4: CASE STUDY- AUTOMOTIVE INDUSTRY}

This chapter describes the application of the above methodology to a large-scale technological analysis of the automotive industry

\subsection{Why is the automotive sector important?}

The automotive sector historically contributed $3-3.5 \%$ to the overall US GDP. It is a major employer of US workers, including a large share of stable well-paying blue-collar jobs. There are about 1.7 million direct jobs in auto manufacturing and sales at dealers and about 8 million private sector jobs impacted by the U.S. auto manufacturers, suppliers and dealers. The key products of this economically crucial sector, vehicle manufacturing and vehicle use, are significant sources of greenhouse gas.

The imperative for reducing carbon and increasing digitalization in all aspects of everyday life have brought new focus to technology change in the automotive industry. Some researchers predict a revolution in urban transportation (Fagnant \& Kockelman, 2015; Fulton, 2018) due to increasing automation, electrification and connectivity-enabled mobility services. However, the industry is capital intensive with low net margins $(\sim 2-5 \%)$. The production planning process is long and requires a multitude of stakeholders, leading to long time delays in the adjustment of production capacity. As such mistakes can be costly and can lead to long-lasting damage to stakeholders including bankruptcies, layoffs and so on.

We use the automotive sector as a use case for the decision-making framework described above. In particular, we focus on technologies related to electric vehicles, automated/ autonomous vehicle and connectivity technologies. 


\subsection{An overview of automotive technologies and their improvement rates}

Since no readily available taxonomy of automotive technologies exists, we relied on the list of products manufactured by the top 100 automotive suppliers from Automotive News (Here's Our Annual Ranking of Top Suppliers, 2020) to create a list of technology search terms (or just technology terms for short). Automotive News is considered as one of the most trustable sources for the automotive industry. We were able to find matching domains for about 326 of the 402 technology terms so obtained. In some instances, multiple technology terms match with the same technology domain (yielding 161 unique domains). This doesn't always mean that they are referring to the same technology- a single technology domain will often contain multiple related technologies. Figure 9 shows the distribution of the estimated improvement rate values for the 326 automotive domains corresponding to the technology term list. Similar to the entire set of 1757 domains for the entire patent system, shown in Figure 2, the best fit for the distribution of estimated improvement rates for automotive technology domains is also a log-normal distribution as shown in Figure 9. The average automotive technology improves at $19.4 \%$ which is almost equal to the average for all 1757 domains. However, we see very few domains which improve above $100 \%$ per annum and none which improve above $200 \%$ per annum which is different from the ful set.

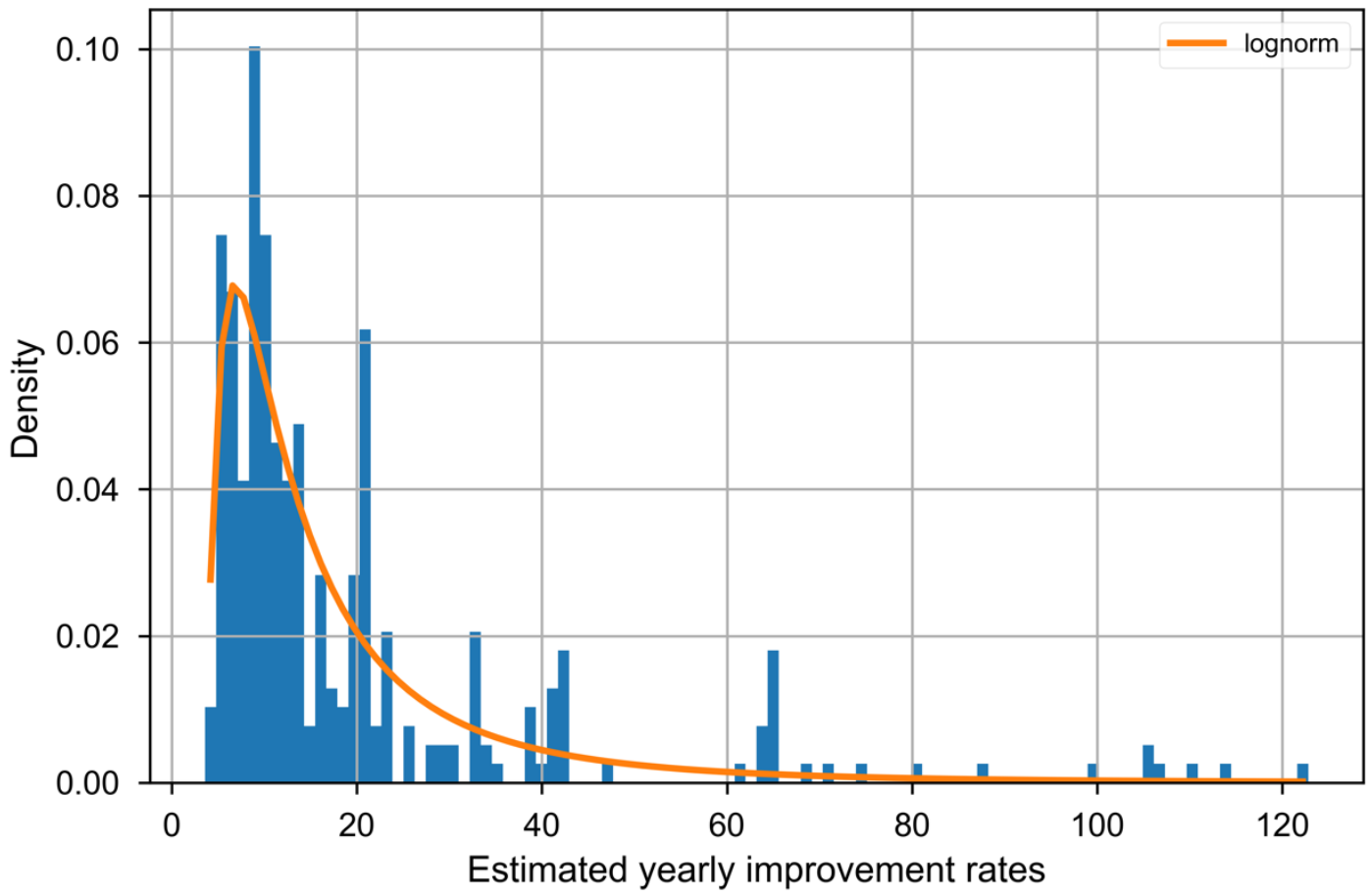

Figure 9 Distribution of Estimated Improvement rates (K-values) for automotive technology domains corresponding to technology term list 
Plotting just the unique technology domains, we get a similar distribution as well as mean rate of improvement (20.06\% per annum), shown in Figure 10.

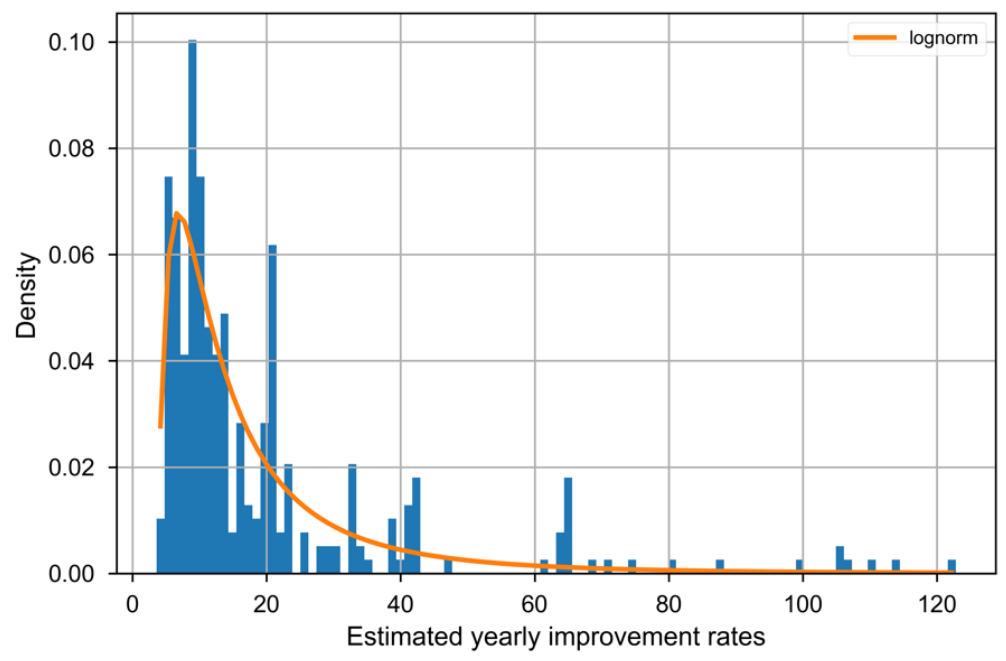

Figure 10 Distribution of Estimated Improvement rates (K-values) for all unique automotive technology domains with no repition of technology domains

Out of the 326 technology terms, for which we were able to retrieve matching patents, 181 had at least 10 matching patents and an MPR greater than or equal to 0.1 suggesting decent quality of match (Figure 11). The mean $(19.04 \%)$ as well as the distribution are similar to the overall set of technology domains.

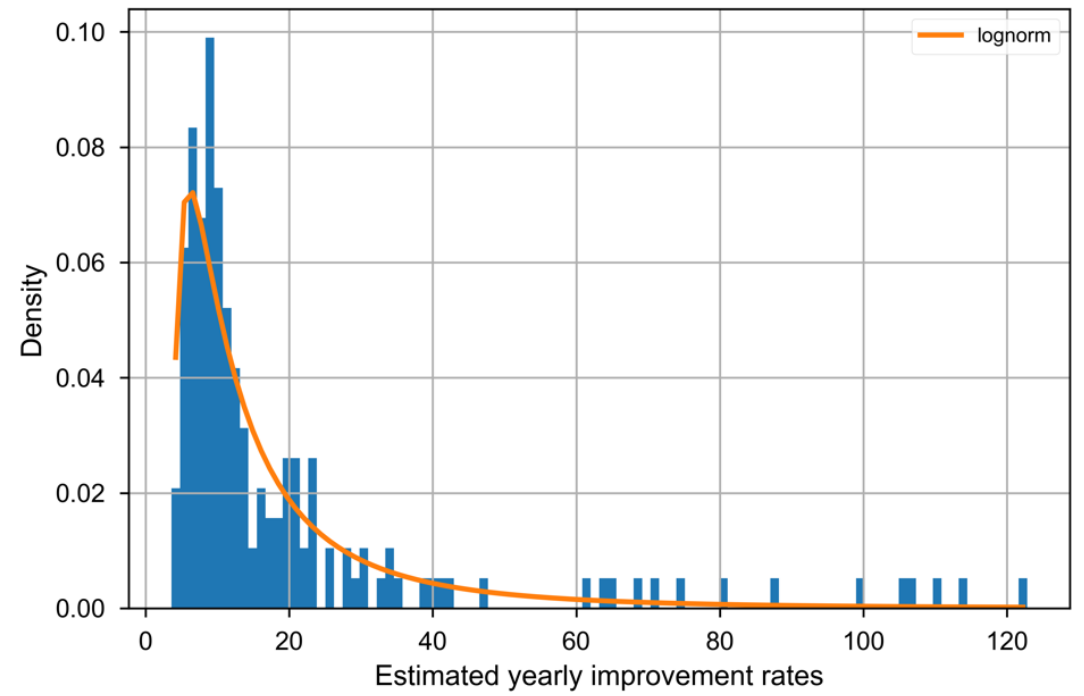

Figure 11 Distribution of Estimated Improvement rates (K-values) for automotive technology domains corresponding to technology term list filtered by number of matches (greater than or equal to 10) and MPR (greater than or equal to 0.1) 


\subsection{A more detailed view of automotive technologies and their improvement rates}

The identification of the technology in the largest 25 domains is given in Table 1. The domains are identified by the Domain ID- a portmanteau of the UPC code and IPC code of the underlying overlapped classes. The estimated improvement rate (estimated K) i.e. the values from Equation 2 are also given along with the domain size i.e. the number of patents (after deduplication). The estimated rates of improvement are reported as percentage change per annum. The improvement rates vary from a low of $10.3 \%$ per year for Fluid separation through filteration, adsorption, chromatography, reverse osmosis etc. (210B01D) domain to a high of $70.5 \%$ per year for the Telecommuniation (379H04M) domain.

Table 1 Biggest 25 automotive domains found using their corresponding search terms

\begin{tabular}{|c|c|c|c|c|c|c|}
\hline $\begin{array}{c}\text { Technology } \\
\text { Term }\end{array}$ & $\begin{array}{l}\text { Domain } \\
\text { ID }\end{array}$ & $\begin{array}{c}\text { Estimated } \\
\text { Improvement } \\
\text { Rate (p.a) }\end{array}$ & $\begin{array}{l}\text { Domain } \\
\text { Size }\end{array}$ & $\begin{array}{c}\text { Domain } \\
\text { Description }\end{array}$ & $\begin{array}{l}\text { Patents } \\
\text { Matched }\end{array}$ & MPR \\
\hline HMI & $257 \mathrm{H} 01 \mathrm{~L}$ & 42.6 & 233828 & $\begin{array}{l}\text { Semiconductor } \\
\text { devices and their } \\
\text { fabrication }\end{array}$ & 2869 & 0.14 \\
\hline $\begin{array}{l}\text { cooling } \\
\text { module }\end{array}$ & $257 \mathrm{H} 01 \mathrm{~L}$ & 42.6 & 233828 & $\begin{array}{l}\text { Semiconductor } \\
\text { devices and their } \\
\text { fabrication }\end{array}$ & 64 & 0.10 \\
\hline $\begin{array}{c}\text { power } \\
\text { semiconductor }\end{array}$ & $257 \mathrm{H} 01 \mathrm{~L}$ & 42.6 & 233828 & $\begin{array}{l}\text { Semiconductor } \\
\text { devices and their } \\
\text { fabrication }\end{array}$ & 1367 & 0.34 \\
\hline optoelectronic & $257 \mathrm{H} 01 \mathrm{~L}$ & 42.6 & 233828 & $\begin{array}{l}\text { Semiconductor } \\
\text { devices and their } \\
\text { fabrication }\end{array}$ & 1287 & 0.17 \\
\hline $\begin{array}{c}\text { power } \\
\text { application }\end{array}$ & $257 \mathrm{H} 01 \mathrm{~L}$ & 42.6 & 233828 & $\begin{array}{l}\text { Semiconductor } \\
\text { devices and their } \\
\text { fabrication }\end{array}$ & 128 & 0.11 \\
\hline $\begin{array}{c}\text { power } \\
\text { distribution } \\
\text { box }\end{array}$ & 439H01R & 17 & 51528 & $\begin{array}{l}\text { Electrical } \\
\text { connectors }\end{array}$ & 16 & 0.24 \\
\hline wiring harness & 439H01R & 17 & 51528 & $\begin{array}{l}\text { Electrical } \\
\text { connectors }\end{array}$ & 187 & 0.12 \\
\hline connector & 439H01R & 17 & 51528 & $\begin{array}{l}\text { Electrical } \\
\text { connectors }\end{array}$ & 34021 & 0.52 \\
\hline HUD & 359G02B & 19.6 & 45782 & $\begin{array}{l}\text { Optical elements } \\
\text { for image } \\
\text { generation,manip } \\
\text { ulation and } \\
\text { enhancement } \\
\text { recently } \\
\text { emphasizing } \\
\text { electo-optics }\end{array}$ & 44 & 0.11 \\
\hline
\end{tabular}




\begin{tabular}{|c|c|c|c|c|c|c|}
\hline head-up & 359G02B & 19.6 & 45782 & $\begin{array}{l}\text { Optical elements } \\
\text { for image } \\
\text { generation,manip } \\
\text { ulation and } \\
\text { enhancement } \\
\text { recently } \\
\text { emphasizing } \\
\text { electo-optics }\end{array}$ & 211 & 0.24 \\
\hline e-compressor & $455 \mathrm{H} 04 \mathrm{~B}$ & 38.8 & 42583 & $\begin{array}{l}\text { Radio-frequency } \\
\text { (Rf) management } \\
\text { in radio-based } \\
\text { communication } \\
\text { networks }\end{array}$ & 17 & 0.12 \\
\hline floor mat & 428B32B & 11 & 36296 & $\begin{array}{c}\text { Multilayered } \\
\text { structures } \\
\text { including coating } \\
\text { and laminates for } \\
\text { heat and wear } \\
\text { resistance }\end{array}$ & 76 & 0.10 \\
\hline $\begin{array}{l}\text { battery } \\
\text { material }\end{array}$ & $429 \mathrm{H} 01 \mathrm{M}$ & 13.3 & 31074 & $\begin{array}{c}\text { Non-aqueus } \\
\text { batteries and fuel } \\
\text { cells }\end{array}$ & 32 & 0.36 \\
\hline batteries & $429 \mathrm{H} 01 \mathrm{M}$ & 13.3 & 31074 & $\begin{array}{c}\text { Non-aqueus } \\
\text { batteries and fuel } \\
\text { cells }\end{array}$ & 3228 & 0.22 \\
\hline $\begin{array}{l}\text { battery } \\
\text { cooling }\end{array}$ & $429 \mathrm{H} 01 \mathrm{M}$ & 13.3 & 31074 & $\begin{array}{c}\text { Non-aqueus } \\
\text { batteries and fuel } \\
\text { cells }\end{array}$ & 40 & 0.25 \\
\hline $\begin{array}{c}\text { battery } \\
\text { enclosure }\end{array}$ & $429 \mathrm{H} 01 \mathrm{M}$ & 13.3 & 31074 & $\begin{array}{c}\text { Non-aqueus } \\
\text { batteries and fuel } \\
\text { cells }\end{array}$ & 22 & 0.24 \\
\hline $\begin{array}{l}\text { battery } \\
\text { housing }\end{array}$ & 429H01M & 13.3 & 31074 & $\begin{array}{l}\text { Non-aqueus } \\
\text { batteries and fuel } \\
\text { cells }\end{array}$ & 174 & 0.21 \\
\hline $\begin{array}{c}\text { Electric } \\
\text { batteries }\end{array}$ & $429 \mathrm{H} 01 \mathrm{M}$ & 13.3 & 31074 & $\begin{array}{c}\text { Non-aqueus } \\
\text { batteries and fuel } \\
\text { cells }\end{array}$ & 16 & 0.17 \\
\hline $\begin{array}{c}\text { injection } \\
\text { molding }\end{array}$ & 264B29C & 11.4 & 28751 & $\begin{array}{c}\text { Injection } \\
\text { moulding and } \\
\text { Heat treatment of } \\
\text { plastics }\end{array}$ & 2971 & 0.22 \\
\hline $\begin{array}{c}\text { automotive } \\
\text { interior }\end{array}$ & 264B29C & 11.4 & 28751 & $\begin{array}{c}\text { Injection } \\
\text { moulding and } \\
\text { Heat treatment of } \\
\text { plastics }\end{array}$ & 35 & 0.10 \\
\hline plastic part & 264B29C & 11.4 & 28751 & $\begin{array}{c}\text { Injection } \\
\text { moulding and } \\
\text { Heat treatment of } \\
\text { plastics }\end{array}$ & 261 & 0.11 \\
\hline
\end{tabular}




\begin{tabular}{|c|c|c|c|c|c|c|}
\hline filtration & 210B01D & 10.3 & 27648 & $\begin{array}{l}\text { Fluid separation } \\
\text { through } \\
\text { filteration, } \\
\text { adsorption, } \\
\text { chromatography, } \\
\text { reverse osmosis } \\
\text { etc. }\end{array}$ & 4111 & 0.23 \\
\hline oil filter & 210B01D & 10.3 & 27648 & $\begin{array}{l}\text { Fluid separation } \\
\text { through } \\
\text { filteration, } \\
\text { adsorption, } \\
\text { chromatography, } \\
\text { reverse osmosis } \\
\text { etc. }\end{array}$ & 387 & 0.22 \\
\hline $\begin{array}{l}\text { telecommunic } \\
\text { ation }\end{array}$ & 379H04M & 70.5 & 26853 & $\begin{array}{c}\text { Data-driven } \\
\text { applications on } \\
\text { Phones } \\
\text { particularly VOIP, } \\
\text { remote control of } \\
\text { devices and } \\
\text { mesaaging etc. }\end{array}$ & 2878 & 0.14 \\
\hline $\begin{array}{l}\text { security } \\
\text { system }\end{array}$ & 340G08B & 25.7 & 22248 & $\begin{array}{l}\text { Electronic } \\
\text { Security systems } \\
\text { for physical } \\
\text { security }\end{array}$ & 961 & 0.15 \\
\hline
\end{tabular}


The identification of the technology of the fastest 10 domains is given in Table 2. The domains are identified by the Domain ID- a portmanteau of the UPC code and IPC code of the underlying overlapped classes, along with the Top 5 assignees in each domain.

Table 2 Fastest improving 10 domains found using their corresponding search terms

\begin{tabular}{|c|c|c|c|c|c|c|}
\hline $\begin{array}{c}\text { Technology } \\
\text { Term }\end{array}$ & $\begin{array}{l}\text { Domain } \\
\text { ID }\end{array}$ & $\begin{array}{c}\text { Estimated } \\
\text { Improvement } \\
\text { Rate (p.a) }\end{array}$ & $\begin{array}{l}\text { Domain } \\
\text { Size }\end{array}$ & Top 5 Assignees & $\begin{array}{l}\text { Patents } \\
\text { Matched }\end{array}$ & MPR \\
\hline valve-timing & 123F02D & 107.3 & 9212 & $\begin{array}{c}\text { Toyota Jidosha } \\
\text { Kabushiki Kaisha, } \\
\text { Robert Bosch Gmbh, } \\
\text { Honda Giken Kogyo } \\
\text { Kabushiki Kaisha, } \\
\text { Nissan Motor Co Ltd, } \\
\text { Ford Global } \\
\text { Technologies Llc }\end{array}$ & 10 & 0.24 \\
\hline $\begin{array}{c}\text { torque } \\
\text { management }\end{array}$ & $477 \mathrm{~F} 16 \mathrm{H}$ & 105.6 & 4119 & $\begin{array}{l}\text { Toyota Jidosha } \\
\text { Kabushiki Kaisha, } \\
\text { Nissan Motor Co Ltd, } \\
\text { Honda Giken Kogyo } \\
\text { Kabushiki Kaisha, } \\
\text { Jatco Ltd, Mazda } \\
\text { Motor Corp }\end{array}$ & 11 & 0.12 \\
\hline $\begin{array}{l}\text { Automatic } \\
\text { transmission }\end{array}$ & $477 \mathrm{~F} 16 \mathrm{H}$ & 105.6 & 4119 & $\begin{array}{c}\text { Toyota Jidosha } \\
\text { Kabushiki Kaisha, } \\
\text { Nissan Motor Co Ltd, } \\
\text { Honda Giken Kogyo } \\
\text { Kabushiki Kaisha, } \\
\text { Jatco Ltd, Mazda } \\
\text { Motor Corp }\end{array}$ & 1811 & 0.37 \\
\hline ECU & $712 \mathrm{G} 06 \mathrm{~F}$ & 87.7 & 8732 & $\begin{array}{l}\text { International Business } \\
\text { Machines Corp, Intel } \\
\text { Corp, Advanced } \\
\text { Micro Devices Corp, } \\
\text { Sun Microsystems } \\
\text { Corp, Hitachi Ltd }\end{array}$ & 4790 & 0.28 \\
\hline $\begin{array}{l}\text { telecommun } \\
\text { ication }\end{array}$ & 379H04M & 70.5 & 26853 & $\begin{array}{c}\text { At\&T Intellectual } \\
\text { Property I Lp, At\&T } \\
\text { Corp, International } \\
\text { Business Machines } \\
\text { Corp, Lucent } \\
\text { Technologies Corp, } \\
\text { Cisco Technology } \\
\text { Corp }\end{array}$ & 2878 & 0.14 \\
\hline
\end{tabular}




\begin{tabular}{|c|c|c|c|c|c|c|}
\hline $\begin{array}{l}\text { catalytic } \\
\text { converter }\end{array}$ & $60 \mathrm{~F} 01 \mathrm{~N}$ & 64.7 & 6832 & $\begin{array}{c}\text { Toyota Jidosha } \\
\text { Kabushiki Kaisha, } \\
\text { Ford Global } \\
\text { Technologies Llc, Gm } \\
\text { Global Technology } \\
\text { Operations Llc, Nissan } \\
\text { Motor Co Ltd, Robert } \\
\text { Bosch Gmbh }\end{array}$ & 1019 & 0.29 \\
\hline $\begin{array}{l}\text { particulate } \\
\text { filter }\end{array}$ & $60 \mathrm{~F} 01 \mathrm{~N}$ & 64.7 & 6832 & $\begin{array}{c}\text { Toyota Jidosha } \\
\text { Kabushiki Kaisha, } \\
\text { Ford Global } \\
\text { Technologies Llc, Gm } \\
\text { Global Technology } \\
\text { Operations Llc, Nissan } \\
\text { Motor Co Ltd, Robert } \\
\text { Bosch Gmbh }\end{array}$ & 639 & 0.29 \\
\hline $\begin{array}{l}\text { engine } \\
\text { exhaust }\end{array}$ & $60 \mathrm{~F} 01 \mathrm{~N}$ & 64.7 & 6832 & $\begin{array}{c}\text { Toyota Jidosha } \\
\text { Kabushiki Kaisha, } \\
\text { Ford Global } \\
\text { Technologies Llc, Gm } \\
\text { Global Technology } \\
\text { Operations Llc, Nissan } \\
\text { Motor Co Ltd, Robert } \\
\text { Bosch Gmbh }\end{array}$ & 746 & 0.20 \\
\hline $\begin{array}{l}\text { exhaust } \\
\text { system }\end{array}$ & $60 \mathrm{~F} 01 \mathrm{~N}$ & 64.7 & 6832 & $\begin{array}{c}\text { Toyota Jidosha } \\
\text { Kabushiki Kaisha, } \\
\text { Ford Global } \\
\text { Technologies Llc, Gm } \\
\text { Global Technology } \\
\text { Operations Llc, Nissan } \\
\text { Motor Co Ltd, Robert } \\
\text { Bosch Gmbh }\end{array}$ & 1143 & 0.23 \\
\hline $\begin{array}{c}\text { diesel } \\
\text { aftertreatme } \\
\mathrm{nt}\end{array}$ & $60 \mathrm{~F} 01 \mathrm{~N}$ & 64.7 & 6832 & $\begin{array}{c}\text { Toyota Jidosha } \\
\text { Kabushiki Kaisha, } \\
\text { Ford Global } \\
\text { Technologies Llc, Gm } \\
\text { Global Technology } \\
\text { Operations Llc, Nissan } \\
\text { Motor Co Ltd, Robert } \\
\text { Bosch Gmbh }\end{array}$ & 11 & 0.39 \\
\hline
\end{tabular}




\subsection{A survey of technologies related to electrification}

We now examine specifically the electrification-related technologies. In addition to the electrificationrelated technology terms obtained from the Automotive News of top 100 supplier technologies, we supplement electrification-related technology term list with additional terms from Feng and Magee (2020), consisting of a detailed study on technologies underpinning electric vehicles. As in section 4.3, we only keep those results with at least 10 matching patents and an MPR greater than or equal to 0.1 to ensure decent quality of match. We find 5 technology domains corresponding to 9 technology terms with rates varying from $20.7 \%$ per annum to $8.8 \%$ per annum as shown in Table 3 .

Table 3 Electrification related technologies found using their corresponding search terms

\begin{tabular}{|c|c|c|c|c|c|c|}
\hline $\begin{array}{c}\text { Technology } \\
\text { Term }\end{array}$ & $\begin{array}{c}\text { Domain } \\
\text { ID }\end{array}$ & $\begin{array}{c}\text { Estimated } \\
\text { Improvement } \\
\text { Rate (p.a) }\end{array}$ & $\begin{array}{c}\text { Domain } \\
\text { Size }\end{array}$ & Top 5 Assignees & $\begin{array}{c}\text { Patents } \\
\text { Matched }\end{array}$ & MPR \\
\hline $\begin{array}{c}\text { electric } \\
\text { powertrain }\end{array}$ & $180 \mathrm{~B} 60 \mathrm{~K}$ & 20.7 & 10683 & $\begin{array}{c}\text { Toyota Jidosha } \\
\text { Kabushiki Kaisha, } \\
\text { Nissan Motor Co Ltd, } \\
\text { Honda Giken Kogyo } \\
\text { Kabushiki Kaisha, } \\
\text { Honda Motor Co Ltd, } \\
\text { Ford Global } \\
\text { Technologies Llc }\end{array}$ & 15 & 0.18 \\
\hline $\begin{array}{l}\text { Induction } \\
\text { motor }\end{array}$ & $318 \mathrm{H} 02 \mathrm{P}$ & 20.3 & 12081 & $\begin{array}{c}\text { General Electric Co, } \\
\text { Hitachi Ltd, Denso } \\
\text { Corp, Mitsubishi } \\
\text { Denki Kabushiki } \\
\text { Kaisha, Matsushita } \\
\text { Electric Industrial Co } \\
\text { Ltd }\end{array}$ & 793 & 0.28 \\
\hline Charging & $320 \mathrm{H} 02 \mathrm{~J}$ & 19.9 & 7634 & $\begin{array}{c}\text { Motorola Corp, } \\
\text { Toyota Jidosha } \\
\text { Kabushiki Kaisha, } \\
\text { Sanyo Electric Co Ltd, } \\
\text { Sony Corp, Hitachi } \\
\text { Ltd }\end{array}$ & 4511 & 0.34 \\
\hline Battery & $320 \mathrm{H} 02 \mathrm{~J}$ & 19.9 & 7634 & $\begin{array}{c}\text { Motorola Corp, } \\
\text { Toyota Jidosha } \\
\text { Kabushiki Kaisha, } \\
\text { Sanyo Electric Co Ltd, } \\
\text { Sony Corp, Hitachi } \\
\text { Ltd }\end{array}$ & 6042 & 0.45 \\
\hline
\end{tabular}




\begin{tabular}{|c|c|c|c|c|c|c|}
\hline $\begin{array}{l}\text { Lead-acid } \\
\text { battery }\end{array}$ & $429 \mathrm{H} 01 \mathrm{M}$ & 13.3 & 31074 & $\begin{array}{l}\text { Samsung Sdi Co Ltd, } \\
\text { Toyota Jidosha } \\
\text { Kabushiki Kaisha, } \\
\text { Matsushita Electric } \\
\text { Industrial Co Ltd, } \\
\text { Sanyo Electric Co Ltd, } \\
\text { Sony Corp }\end{array}$ & 207 & 0.35 \\
\hline $\begin{array}{l}\text { Lithium- } \\
\text { ion battery }\end{array}$ & $429 \mathrm{H} 01 \mathrm{M}$ & 13.3 & 31074 & $\begin{array}{l}\text { Samsung Sdi Co Ltd, } \\
\text { Toyota Jidosha } \\
\text { Kabushiki Kaisha, } \\
\text { Matsushita Electric } \\
\text { Industrial Co Ltd, } \\
\text { Sanyo Electric Co Ltd, } \\
\text { Sony Corp }\end{array}$ & 142 & 0.33 \\
\hline $\begin{array}{l}\text { battery } \\
\text { cooling }\end{array}$ & 429H01M & 13.3 & 31074 & $\begin{array}{l}\text { Samsung Sdi Co Ltd, } \\
\text { Toyota Jidosha } \\
\text { Kabushiki Kaisha, } \\
\text { Matsushita Electric } \\
\text { Industrial Co Ltd, } \\
\text { Sanyo Electric Co Ltd, } \\
\text { Sony Corp }\end{array}$ & 40 & 0.25 \\
\hline $\begin{array}{c}\text { Electric } \\
\text { motor }\end{array}$ & $310 \mathrm{H} 02 \mathrm{~K}$ & 8.8 & 20891 & $\begin{array}{c}\text { General Electric Co, } \\
\text { Mitsubishi Denki } \\
\text { Kabushiki Kaisha, } \\
\text { Denso Corp, Hitachi } \\
\text { Ltd, Siemens } \\
\text { Aktiengesellschaft }\end{array}$ & 2966 & 0.15 \\
\hline $\begin{array}{c}\text { Permanent } \\
\text { magnet } \\
\text { motor }\end{array}$ & $310 \mathrm{H} 02 \mathrm{~K}$ & 8.8 & 20891 & $\begin{array}{c}\text { General Electric Co, } \\
\text { Mitsubishi Denki } \\
\text { Kabushiki Kaisha, } \\
\text { Denso Corp, Hitachi } \\
\text { Ltd, Siemens } \\
\text { Aktiengesellschaft }\end{array}$ & 207 & 0.24 \\
\hline
\end{tabular}




\subsection{A survey of technologies related to automated/ autonomous vehicles}

We now examine specifically the automated/ autonomous vehicles technologies. In addition to the technology terms obtained from the Automotive News of top 100 supplier technologies, we supplement the technology term list with additional terms from Pendleton et al. (2017) and Badue et al. (2019), describing key technologies and systems in automated/ autonomous vehicles. As in section 4.3 and section 4.4, we ony keep those results with at least 10 matching patents and an MPR greater than or equal to 0.1 to ensure decent quality of match.

We find 7 technology domains corresponding to 10 technology terms with rates varying from $113.9 \%$ per annum to $20.7 \%$ per annum as shown in Table 4 . The automation technologies we found are mostly based on software and improve much faster than electrification-related technologies similar to the finding in Singh et al. (2020) about the total technology system.

Table 4 Automated/Autonomous vehicle related technologies found using their corresponding search terms

\begin{tabular}{|c|c|c|c|c|c|c|}
\hline $\begin{array}{c}\text { Technology } \\
\text { Term }\end{array}$ & $\begin{array}{c}\text { Domain } \\
\text { ID }\end{array}$ & $\begin{array}{c}\text { Estimated } \\
\text { Improvement } \\
\text { Rate (p.a) }\end{array}$ & $\begin{array}{l}\text { Domain } \\
\text { Size }\end{array}$ & Top 5 Assignees & $\begin{array}{l}\text { Patents } \\
\text { Matched }\end{array}$ & MPR \\
\hline $\begin{array}{c}\text { Path } \\
\text { Estimation }\end{array}$ & $370 \mathrm{H} 04 \mathrm{~L}$ & 113.9 & 73936 & $\begin{array}{l}\text { Cisco Technology } \\
\text { Corp, International } \\
\text { Business Machines } \\
\text { Corp, Fujitsu Ltd, } \\
\text { Telefonaktiebolaget } \\
\text { Lm Ericsson (Publ), } \\
\text { Qualcomm Corp }\end{array}$ & 12 & 0.12 \\
\hline $\begin{array}{c}\text { Route } \\
\text { Planning }\end{array}$ & $701 \mathrm{G} 01 \mathrm{C}$ & 63.6 & 6300 & $\begin{array}{c}\text { Honeywell } \\
\text { International Corp, } \\
\text { Denso Corp, Aisin Aw } \\
\text { Co Ltd, The Boeing } \\
\text { Co, Alpine Electronics } \\
\text { Corp }\end{array}$ & 70 & 0.26 \\
\hline Vision & $348 \mathrm{H} 04 \mathrm{~N}$ & 46.7 & 83993 & $\begin{array}{c}\text { Sony Corp, Canon } \\
\text { Kabushiki Kaisha, } \\
\text { Samsung Electronics } \\
\text { Co Ltd, Matsushita } \\
\text { Electric Industrial Co } \\
\text { Ltd, Kabushiki Kaisha } \\
\text { Toshiba }\end{array}$ & 12270 & 0.16 \\
\hline
\end{tabular}




\begin{tabular}{|c|c|c|c|c|c|c|}
\hline $\begin{array}{c}\text { Model } \\
\text { Predictive } \\
\text { Control }\end{array}$ & 700G05B & 42.1 & 7988 & $\begin{array}{c}\text { Fanuc Corp, } \\
\text { Mitsubishi Denki } \\
\text { Kabushiki Kaisha, } \\
\text { Siemens } \\
\text { Aktiengesellschaft, } \\
\text { Hitachi Ltd, } \\
\text { Honeywell } \\
\text { International Corp }\end{array}$ & 60 & 0.25 \\
\hline $\begin{array}{l}\text { Collision } \\
\text { Avoidance }\end{array}$ & $342 \mathrm{G} 01 \mathrm{~S}$ & 29.7 & 15539 & $\begin{array}{c}\text { Raytheon Co, The } \\
\text { United States Of } \\
\text { America As } \\
\text { Represented By The } \\
\text { Secretary Of The } \\
\text { Navy, Trimble } \\
\text { Navigation Ltd, } \\
\text { Honeywell } \\
\text { International Corp, } \\
\text { Lockheed Martin Corp }\end{array}$ & 184 & 0.14 \\
\hline $\begin{array}{c}\text { Collision } \\
\text { warning }\end{array}$ & $342 \mathrm{G} 01 \mathrm{~S}$ & 29.7 & 15539 & $\begin{array}{c}\text { Raytheon Co, The } \\
\text { United States Of } \\
\text { America As } \\
\text { Represented By The } \\
\text { Secretary Of The } \\
\text { Navy, Trimble } \\
\text { Navigation Ltd, } \\
\text { Honeywell } \\
\text { International Corp, } \\
\text { Lockheed Martin Corp }\end{array}$ & 24 & 0.11 \\
\hline Radar & $342 \mathrm{G} 01 \mathrm{~S}$ & 29.7 & 15539 & $\begin{array}{c}\text { Raytheon Co, The } \\
\text { United States Of } \\
\text { America As } \\
\text { Represented By The } \\
\text { Secretary Of The } \\
\text { Navy, Trimble } \\
\text { Navigation Ltd, } \\
\text { Honeywell } \\
\text { International Corp, } \\
\text { Lockheed Martin Corp }\end{array}$ & 5537 & 0.51 \\
\hline $\begin{array}{c}\text { Target } \\
\text { Classificatio } \\
\mathrm{n}\end{array}$ & $342 \mathrm{G} 01 \mathrm{~S}$ & 29.7 & 15539 & $\begin{array}{l}\text { Raytheon Co, The } \\
\text { United States Of } \\
\text { America As } \\
\text { Represented By The } \\
\text { Secretary Of The } \\
\text { Navy, Trimble } \\
\text { Navigation Ltd, } \\
\text { Honeywell } \\
\text { International Corp, } \\
\text { Lockheed Martin Corp }\end{array}$ & 11 & 0.20 \\
\hline
\end{tabular}




\begin{tabular}{|c|c|c|c|c|c|c|}
\hline $\begin{array}{l}\text { Autonomou } \\
\text { s Vehicle }\end{array}$ & 701G05D & 21.4 & 2017 & $\begin{array}{c}\text { The Boeing Co, } \\
\text { General Electric Co, } \\
\text { Toyota Jidosha } \\
\text { Kabushiki Kaisha, } \\
\text { Honeywell } \\
\text { International Corp, } \\
\text { Google Corp }\end{array}$ & 64 & 0.17 \\
\hline $\begin{array}{c}\text { Adaptive } \\
\text { Cruise } \\
\text { Control }\end{array}$ & $180 \mathrm{~B} 60 \mathrm{~K}$ & 20.7 & 10683 & $\begin{array}{c}\text { Toyota Jidosha } \\
\text { Kabushiki Kaisha, } \\
\text { Nissan Motor Co Ltd, } \\
\text { Honda Giken Kogyo } \\
\text { Kabushiki Kaisha, } \\
\text { Honda Motor Co Ltd, } \\
\text { Ford Global } \\
\text { Technologies Llc }\end{array}$ & 30 & 0.14 \\
\hline
\end{tabular}




\subsection{A survey of technologies related to Mobility services}

Finally, we examine connectivity-enabled mobility service technologies. In addition to the technology terms obtained from the Automotive News of top 100 supplier technologies, we supplement the technology term list with additional terms from Reyes García et al., (2020) and Pihlajamaa et al. (2013) describing the architecture for Mobility as a service (MAAS). As in section 4.3 and section 4.4, we only keep those results with at least 10 matching patents and an MPR greater than or equal to 0.1 to ensure decent quality of match.

We find 7 technology domains corresponding to 9 technology terms with rates varying from $228.8 \%$ per annum to $13 \%$ per annum as shown in Table 5 . The technologies related to mobility services are mostly based on software and again seen to improve much faster than electrification-related technologies.

Table 5 Connectivity enabled Mobility services related technologies found using their corresponding search terms

\begin{tabular}{|c|c|c|c|c|c|c|}
\hline $\begin{array}{c}\text { Technology } \\
\text { Term }\end{array}$ & $\begin{array}{l}\text { Domain } \\
\text { ID }\end{array}$ & $\begin{array}{c}\text { Estimated } \\
\text { Improvement } \\
\text { Rate (p.a) }\end{array}$ & $\begin{array}{c}\text { Domain } \\
\text { Size }\end{array}$ & Top 5 Assignees & $\begin{array}{l}\text { Patents } \\
\text { Matched }\end{array}$ & MPR \\
\hline $\begin{array}{c}\text { Remote } \\
\text { Access }\end{array}$ & 709G06F & 228.8 & 64667 & $\begin{array}{l}\text { Engate Technology } \\
\text { Corp, International } \\
\text { Business Machines } \\
\text { Corp, Microsoft Corp, } \\
\text { Cisco Technology } \\
\text { Corp, Hewlett-Packard } \\
\text { Development Co Lp }\end{array}$ & 242 & 0.13 \\
\hline $\begin{array}{c}\text { User } \\
\text { Manageme } \\
\text { nt }\end{array}$ & 709G06F & 228.8 & 64667 & $\begin{array}{l}\text { Engate Technology } \\
\text { Corp, International } \\
\text { Business Machines } \\
\text { Corp, Microsoft Corp, } \\
\text { Cisco Technology } \\
\text { Corp, Hewlett-Packard } \\
\text { Development Co Lp }\end{array}$ & 25 & 0.13 \\
\hline $\begin{array}{c}\text { Optimizatio } \\
\text { n Engine }\end{array}$ & 705G06Q & 122.8 & 34726 & $\begin{array}{l}\text { International Business } \\
\text { Machines Corp, Sap } \\
\text { Ag, Google Corp, } \\
\text { Trading Technologies } \\
\text { International Corp, } \\
\text { Amazon Technologies } \\
\text { Corp }\end{array}$ & 20 & 0.16 \\
\hline
\end{tabular}




\begin{tabular}{|c|c|c|c|c|c|c|}
\hline $\begin{array}{c}\text { Payment } \\
\text { Manageme } \\
\text { nt }\end{array}$ & 705G06Q & 122.8 & 34726 & $\begin{array}{l}\text { International Business } \\
\text { Machines Corp, Sap } \\
\text { Ag, Google Corp, } \\
\text { Trading Technologies } \\
\text { International Corp, } \\
\text { Amazon Technologies } \\
\text { Corp }\end{array}$ & 34 & 0.45 \\
\hline $\begin{array}{l}\text { Real-time } \\
\text { tracking }\end{array}$ & $382 \mathrm{G} 06 \mathrm{~K}$ & 42.1 & 41123 & $\begin{array}{l}\text { Canon Kabushiki } \\
\text { Kaisha, Microsoft } \\
\text { Corp, Sony Corp, } \\
\text { Samsung Electronics } \\
\text { Co Ltd, Xerox Corp }\end{array}$ & 13 & 0.12 \\
\hline OBD & $701 \mathrm{G} 06 \mathrm{~F}$ & 41.2 & 8538 & $\begin{array}{c}\text { Gm Global } \\
\text { Technology } \\
\text { Operations Llc, } \\
\text { Toyota Jidosha } \\
\text { Kabushiki Kaisha, } \\
\text { Ford Global } \\
\text { Technologies Llc, } \\
\text { Denso Corp, Honda } \\
\text { Motor Co Ltd }\end{array}$ & 31 & 0.11 \\
\hline $\begin{array}{l}\text { Vehicle-to- } \\
\text { vehicle }\end{array}$ & 340G08G & 39.7 & 3289 & $\begin{array}{l}\text { International Business } \\
\text { Machines Corp, Denso } \\
\text { Corp, Toyota Jidosha } \\
\text { Kabushiki Kaisha, } \\
\text { Nissan Motor Co Ltd, } \\
\text { Robert Bosch Gmbh }\end{array}$ & 22 & 0.12 \\
\hline DSRC & $455 \mathrm{H} 04 \mathrm{~B}$ & 38.8 & 42583 & $\begin{array}{c}\text { Motorola Corp, } \\
\text { Samsung Electronics } \\
\text { Co Ltd, Qualcomm } \\
\text { Corp, Broadcom Corp, } \\
\text { Nec Corp }\end{array}$ & 14 & 0.14 \\
\hline Telemetry & 340E21B & 13 & 116 & $\begin{array}{l}\text { Halliburton Energy } \\
\text { Services Corp, } \\
\text { Schlumberger } \\
\text { Technology Corp, } \\
\text { Baker Hughes Corp, } \\
\text { Hughes Tool Co, } \\
\text { Teleco Oilfield } \\
\text { Services Corp }\end{array}$ & 32 & 0.15 \\
\hline
\end{tabular}




\subsection{Electrification technologies improve slowly, automated/ autonomous technologies are faster but connectivity-related technologies are improving fastest}

The conventional automotive sector generally consists of products built on stable, relatively-slowly improving technologies. Of the three likely drivers of change in automotive industry- electrification, automated/ autonomous, and connectivity enabled mobility services-related technologies, we find that electrification related technologies improve the slowest, as reported in Table 3. Both autonomous vehicle related technologies and connectivity related technologies improve at much faster rates as reported in Table 4 and Table 5. This suggests that automotive industry decision makers need to pay more attention to the faster improving technologies as they are likely to enable completely new products and capabilities such as robotaxis, on-demand mobility experiences etc.

Although the earliest electric cars appeared before the internal combustion engine powered cars, the internal combustion engine proved to be superior in meeting customer needs and quickly captured the market. The first modern mass-produced car with battery-powered locomotion was the Toyota Prius launched in 1997 as a fuel efficieny enhancement technology made possible by advances in batteries as well as control technologies. The hybrid cars (including plug-in hybrids) now account for less than $3 \%$ of all light vehicles sold annually and pure battery electric vehicles account for less than $2 \%$ of all light vehicles sold annually (Davis \& Boundy, 2020). The earliest adaptive cruise control systems were introduced in the 1990s. 10\% of new cars in the US were sold with level 2 autonomy driving features in 2019 (Canalys, 2019). The first telematics systems were launched in the early 1990s and are now standard components on most new vehicles sold. It is hard not to notice that electrification technologies improve slowly and have slower adoption rates while automated/ autonomous and connectivity-related technologies are improving faster and also have higher adoption rates, This relationship between improvement rates and adoption supports the conclusion by Woo and Magee (2018) suggesting that technologies improving at a faster rate have a faster adoption rate especially during their infancy. 


\section{CHAPTER 5: CONCLUSIONS}

This work reviews past work on technological forecasting and decision making and builds on new research to introduce a systematic approach to technological decision-making. We describe the development of a new web-based technology search tool and apply the methodology to a case study of the automotive industry.

Before noting the implications of the results, we first note some limitations concerning the work. First, since this work builds on the framework described by Singh et al. (2020) it suffers from similar limitations including discarding domains smaller than 100 patents and not including domains identified at deeper sub-groups within the UPC and IPC classes rather than just the high- level classes as well as assignment of all duplicate patents to only the largest domain in which they are found. Both these limitations are unlikely to significantly upset our conclusions. As noted in Singh et al. (2020), prior work has generally found much less variation in rates of improvement among sub-domains than across domain (Benson et al., 2018; Sharifzadeh et al., 2019). Similarly, Singh et al. (2020), found no large differences in estimated rate of improvement $(\mathrm{k})$ in specific domains before and after elimination of duplicative patents.

Despite the limitations noted above, we believe these results herald a new era of data-driven technological decision-making. Using this new framework and the open-source publicly available tool described in Section-3, stakeholders can make timely and "good enough" technology forecasts available to the without requiring extensive modelling initiatives. We demonstrate an application of the methodology and the tool through a case study of the automotive sector.

While the automotive sector has been an important pillar of the economy and an important driver of innovation, conventional automotive technologies have tended to improve at much slower rates. The fastest improving technologies in automated/autonomous vehicles as well as connectivity related domains improve at much faster rates. Prior work posits low interaction among components, i.e. modularity, as one of the major causal factors helping explain variation in improvement rates (Basnet \& Magee, 2016; McNerney et al., 2011). Modularity is one of the key characteristics of modern software design and engineering (Carliss Young Baldwin et al., 2000) and is also reflected in the organizational design of software development firms- primarily consisting of small, nimble teams (Abrahamsson et al., 2017; C. Y. Baldwin \& Clark, 1997), often working on self-contained projects with very little interaction between each other. This is made possible by standardized interfaces, among other things, which allow for rapid 
switching of technologies on either side of the interface. This has also enabled and in turn, been enabled by, the open-source movement allowing for quick reuse and repurposing of software. The software morphs with each repurposing and gets better much higher rates by assimilating information faster. It is an open question whether traditional automotive firms will be able to adapt to this technology development paradigm and make the necessary shift successfully to be able to produce good software.

In closing, information on improvement rates is crucial to be able to compute optimal allocation among multiple technologies competing for resources. The open-source public technology search system can be a valuable aid in this regard. As demonstrated by the case study, it enables technology managers and policymakers to quickly look up estimates of improvement rates for specific technologies (or domains) or groups of related technologies. We believe and hope that this will bring greater accuracy, precision and repeatability to the as yet fuzzy art of technology forecasting and help avoid costly mistakes. 


\section{BIBLIOGRAPHY}

Abrahamsson, P., Salo, O., Ronkainen, J., \& Warsta, J. (2017). Agile Software Development Methods: Review and Analysis. ArXiv:1709.08439 [Cs]. http://arxiv.org/abs/1709.08439

Argote, L., \& Epple, D. (1990). Learning Curves in Manufacturing. Science, 247(4945), 920924. https://doi.org/10.1126/science.247.4945.920

Arthur, W. B. (2007). The structure of invention. Research Policy, 36(2), 274-287.

Ayres, R. U., \& Martinàs, K. (1992). Experience and the life cycle: Some analytic implications. Technovation, 12(7), 465-486. https://doi.org/10.1016/0166-4972(92)90052-J

Badue, C., Guidolini, R., Carneiro, R. V., Azevedo, P., Cardoso, V. B., Forechi, A., Jesus, L., Berriel, R., Paixão, T., Mutz, F., Veronese, L., Oliveira-Santos, T., \& De Souza, A. F. (2019). Self-Driving Cars: A Survey. ArXiv:1901.04407 [Cs]. http://arxiv.org/abs/1901.04407

Baldwin, C. Y., \& Clark, K. B. (1997). Managing in an age of modularity. Harvard Business Review, 75(5), 84-93.

Baldwin, Carliss Young, Baldwin, W. L. W. P. of B. A. C. Y., Clark, K. B., \& Clark, P. K. B. (2000). Design Rules: The power of modularity. MIT Press.

Basnet, S., \& Magee, C. L. (2016). Modeling of technological performance trends using design theory. Design Science, 2. https://doi.org/10.1017/dsj.2016.8

Batagelj, V. (2003). Efficient Algorithms for Citation Network Analysis. ArXiv: Cs/0309023. http://arxiv.org/abs/cs/0309023

Benson, C. L., \& Magee, C. L. (2018). Data-Driven Investment Decision-Making: Applying Moore's Law and S-Curves to Business Strategies. ArXiv:1805.06339 [Econ]. http://arxiv.org/abs/1805.06339

Bound, J., Cummins, C., Griliches, Z., Hall, B. H., \& Jaffe, A. B. (1982). Who Does R\&D and Who Patents? (Working Paper No. 908; Working Paper Series). National Bureau of Economic Research. https://doi.org/10.3386/w0908

Canalys: 10\% of new cars in the US sold with level 2 autonomy driving features. (2019, September). https://www.canalys.com/newsroom/canalys-level-2-autonomy-vehicles-USQ2-2019?time $=1596372918$

Czarnitzki, D., \& Hussinger, K. (2004). The Link between R\&D Subsidies, R\&D Spending and Technological Performance (SSRN Scholarly Paper ID 575362). Social Science Research Network. https://doi.org/10.2139/ssrn.575362 
Davis, S., \& Boundy, R. G. (2020). Transportation Energy Data Book: Edition 38. Oak Ridge National Lab.(ORNL), Oak Ridge, TN (United States).

Dosi, G. (1982). Technological paradigms and technological trajectories: A suggested interpretation of the determinants and directions of technical change. Research Policy, 11(3), 147-162. https://doi.org/10.1016/0048-7333(82)90016-6

Dutton, J. M., \& Thomas, A. (1984). Treating Progress Functions as a Managerial Opportunity. The Academy of Management Review, 9(2), 235-247. JSTOR. https://doi.org/10.2307/258437

Fagnant, D. J., \& Kockelman, K. (2015). Preparing a nation for autonomous vehicles: Opportunities, barriers and policy recommendations. Transportation Research Part A: Policy and Practice, 77, 167-181. https://doi.org/10.1016/j.tra.2015.04.003

Farmer, J. D., \& Lafond, F. (2016). How predictable is technological progress? Research Policy, 45(3), 647-665. https://doi.org/10.1016/j.respol.2015.11.001

Feng, S., \& Magee, C. L. (2020). Technological development of key domains in electric vehicles: Improvement rates, technology trajectories and key assignees. Applied Energy, 260, 114264. https://doi.org/10.1016/j.apenergy.2019.114264

Fleming, L. (2001). Recombinant Uncertainty in Technological Search. Management Science, 47(1), 117-132. https://doi.org/10.1287/mnsc.47.1.117.10671

Fleming, L., \& Sorenson, O. (2001). Technology as a complex adaptive system: Evidence from patent data. Research Policy, 30(7), 1019-1039.

Frenken, K. (2006a). Innovation, Evolution and Complexity Theory. Edward Elgar Publishing. https://ideas.repec.org/b/elg/eebook/2939.html

Frenken, K. (2006b). Technological innovation and complexity theory. Economics of Innovation and New Technology, 15(2), 137-155. https://doi.org/10.1080/10438590500141453

Frenken, K. (2006c). A fitness landscape approach to technological complexity, modularity, and vertical disintegration. Structural Change and Economic Dynamics, 17(3), 288-305. https://doi.org/10.1016/j.strueco.2006.01.001

Frenken, K., \& Nuvolari, A. (2004). The early development of the steam engine: An evolutionary interpretation using complexity theory. Industrial and Corporate Change, 13(2), 419-450. https://doi.org/10.1093/icc/dth017

Fulton, L. M. (2018). Three Revolutions in Urban Passenger Travel. Joule, 2(4), 575-578. https://doi.org/10.1016/j.joule.2018.03.005

Funk, J. (2019, October 7). What's Behind Technological Hype? | Issues in Science and Technology. https://issues.org/behind-technological-hype/ 
Funk, J. L., \& Magee, C. L. (2015). Rapid improvements with no commercial production: How do the improvements occur? Research Policy, 44(3), 777-788.

https://doi.org/10.1016/j.respol.2014.11.005

Gruber, M., Harhoff, D., \& Hoisl, K. (2012). Knowledge Recombination Across Technological Boundaries: Scientists vs. Engineers. Management Science, 59(4), 837-851. https://doi.org/10.1287/mnsc.1120.1572

Hall, B. H., Griliches, Z., \& Hausman, J. A. (1984). Patents and R\&D: Is There A Lag? (Working Paper No. 1454; Working Paper Series). National Bureau of Economic Research. https://doi.org/10.3386/w1454

Here's our annual ranking of top suppliers. (2020, June 29). Automotive News. https://www.autonews.com/suppliers/heres-our-annual-ranking-top-suppliers

Hoisl, K., Stelzer, T., \& Biala, S. (2015). Forecasting technological discontinuities in the ICT industry. Research Policy, 44(2), 522-532. https://doi.org/10.1016/j.respol.2014.10.004

Hummon, N. P., \& Dereian, P. (1989). Connectivity in a citation network: The development of DNA theory. Social Networks, 11(1), 39-63. https://doi.org/10.1016/03788733(89)90017-8

Kim, J., \& Marschke, G. (2004). Accounting for the recent surge in U.S. patenting: Changes in R\&D expenditures, patent yields, and the high tech sector. Economics of Innovation and New Technology, 13(6), 543-558. https://doi.org/10.1080/1043859032000124693

Koh, H., \& Magee, C. L. (2006). A functional approach for studying technological progress: Application to information technology. Technological Forecasting and Social Change, 73(9), 1061-1083. https://doi.org/10.1016/j.techfore.2006.06.001

Koh, H., \& Magee, C. L. (2008). A functional approach for studying technological progress: Extension to energy technology. Technological Forecasting and Social Change, 75(6), 735-758. https://doi.org/10.1016/j.techfore.2007.05.007

Koomey, J. G., Berard, S., Sanchez, M., \& Wong, H. (2011). Web Extra Appendix: Implications of Historical Trends in the Electrical Efficiency of Computing. IEEE Annals of the History of Computing, 33(3), S1-S30.

Lafond, F., Greenwald, D. S., \& Farmer, J. D. (2020). Can Stimulating Demand Drive Costs Down? World War II as a Natural Experiment (SSRN Scholarly Paper ID 3519913). Social Science Research Network. https://doi.org/10.2139/ssrn.3519913

Magee, C. L., Basnet, S., Funk, J. L., \& Benson, C. L. (2016). Quantitative empirical trends in technical performance. Technological Forecasting and Social Change, 104, 237-246. https://doi.org/10.1016/j.techfore.2015.12.011 
Martino, J. (1971). Examples of technological trend forecasting for research and development planning. Technological Forecasting and Social Change, 2(3), 247-260.

https://doi.org/10.1016/0040-1625(71)90003-5

McNerney, J., Farmer, J. D., Redner, S., \& Trancik, J. E. (2011). Role of design complexity in technology improvement. Proceedings of the National Academy of Sciences, 108(22), 9008-9013. https://doi.org/10.1073/pnas.1017298108

Moore, G. E. (1965). Cramming more components onto integrated circuits. Electronics Mag., $38(8)$.

Moore, G. E. (2006). Understanding Moore's Law: Four Decades of Innovation (D. C. Brock, Ed.). Chemical Heritage Foundation.

Nagy, B., Farmer, J. D., Bui, Q. M., \& Trancik, J. E. (2013). Statistical Basis for Predicting Technological Progress. PLoS ONE, 8(2). https://doi.org/10.1371/journal.pone.0052669

Nordhaus, W. (2007). Two Centuries of Productivity Growth in Computing. The Journal of Economic History, 67(1), 128-159.

Nordhaus, W.D. (1996). The Economics of New Goods (T. F. Bresnahan \& R. J. Gordon, Eds.). https://www.nber.org/books/bres96-1/

Nordhaus, William D. (2014). The Perils of the Learning Model for Modeling Endogenous Technological Change. The Energy Journal, 35(1), 1-13. JSTOR.

Pakes, A., \& Griliches, Z. (1984). Patents and R\&D at the Firm Level: A First Look (pp. 55-72) [NBER Chapters]. National Bureau of Economic Research, Inc. https://econpapers.repec.org/bookchap/nbrnberch/10044.htm

Pendleton, S. D., Andersen, H., Du, X., Shen, X., Meghjani, M., Eng, Y. H., Rus, D., \& Ang, M. H. (2017). Perception, Planning, Control, and Coordination for Autonomous Vehicles. Machines, 5(1), 6. https://doi.org/10.3390/machines5010006

Pihlajamaa, O., Heino, I., \& Vilkman, A. (2013). Multi-Service Architecture for mobility services. VTT Technical Research Centre of Finland.

https://cris.vtt.fi/en/publications/multi-service-architecture-for-mobility-services

Reyes García, J. R., Lenz, G., Haveman, S. P., \& Bonnema, G. M. (2020). State of the Art of Mobility as a Service (MaaS) Ecosystems and Architectures-An Overview of, and a Definition, Ecosystem and System Architecture for Electric Mobility as a Service (eMaaS). World Electric Vehicle Journal, 11(1), 7. https://doi.org/10.3390/wevj11010007

Ruttan, V. W. (2000). Technology, Growth, and Development: An Induced Innovation Perspective. Oxford University Press. https://ideas.repec.org/b/oxp/obooks/9780195118711.html 
Sahal, D. (1979). A Theory of Progress Functions. A I I E Transactions, 11(1), $23-29$. https://doi.org/10.1080/05695557908974396

Schmookler, J. (1966). Invention and economic growth. Harvard University Press.

Sinclair, G., Klepper, S., \& Cohen, W. (2000). What's Experience Got to Do With It? Sources of Cost Reduction in a Large Specialty Chemicals Producer. Management Science, 46(1), 28-45. https://doi.org/10.1287/mnsc.46.1.28.15133

Singh, A., Triulzi, G., \& Magee, C. L. (2020). Technological Improvement Rate Estimates for All Technologies: Use of Patent Data and an Extended Domain Description (SSRN Scholarly Paper ID 3571060). Social Science Research Network. https://doi.org/10.2139/ssrn.3571060

Triulzi, G., Alstott, J., \& Magee, C. L. (2020). Estimating technology performance improvement rates by mining patent data. Technological Forecasting and Social Change, 158, 120100. https://doi.org/10.1016/j.techfore.2020.120100

Usher, A. P. (1954). A History of mechanical inventions. Abbott Payson Usher ... Revised edition. Mass. : Harvard University Press.

Verspagen, B. (2007). Mapping Technological Trajectories As Patent Citation Networks: A Study On The History Of Fuel Cell Research. Advances in Complex Systems (ACS), 10(01), 93-115.

Weisberg, R. W. (2006). Creativity: Understanding innovation in problem solving, science, invention, and the arts. John Wiley \& Sons Inc.

Woo, J., \& Magee, C. L. (2018). Exploring the relationship between technological improvement and innovation diffusion: An empirical test. ArXiv:1704.03597 [Physics, q-Fin]. http://arxiv.org/abs/1704.03597

Woo, J., \& Magee, C. L. (2020). Forecasting the value of battery electric vehicles compared to internal combustion engine vehicles: The influence of driving range and battery technology. International Journal of Energy Research, 44(8), 6483-6501. https://doi.org/10.1002/er.5382

Wright, T. P. (1936). Factors Affecting the Cost of Airplanes. Journal of the Aeronautical Sciences, 3(4), 122-128. https://doi.org/10.2514/8.155

Youn, H., Strumsky, D., Bettencourt, L. M. A., \& Lobo, J. (2015). Invention as a combinatorial process: Evidence from US patents. Journal of The Royal Society Interface, 12(106), 20150272. https://doi.org/10.1098/rsif.2015.0272 